(2) norden 



\section{Impact of energy labelling on household appliances}

TemaNord 2007:605 
Impact of energy labelling on household appliances

TemaNord 2007:605

(C) Nordic Council of Ministers, Copenhagen 2007

ISBN 978-92-893-1618-7

Print: Ekspressen Tryk \& Kopicenter

\section{Copies: 150}

Printed on environmentally friendly paper

This publication can be ordered on www.norden.org/order. Other Nordic publications are available at www.norden.org/publications

Printed in Denmark

\section{Nordic Council of Ministers}

Store Strandstræde 18

DK-1255 Copenhagen K

Phone (+45) 33960200

Fax (+45) 33960202

\section{Nordic Council}

Store Strandstræde 18

DK-1255 Copenhagen K

Phone (+45) 33960400

Fax (+45) 33111870

www.norden.org

\section{Nordic co-operation}

Nordic cooperation is one of the world's most extensive forms of regional collaboration, involving Denmark, Finland, Iceland, Norway, Sweden, and three autonomous areas: the Faroe Islands, Greenland, and Åland.

Nordic cooperation has firm traditions in politics, the economy, and culture. It plays an important rol in European and international collaboration, and aims at creating a strong Nordic community in a strong Europe.

Nordic cooperation seeks to safeguard Nordic and regional interests and principles in the global community. Common Nordic values help the region solidify its position as one of the world's most innovative and competitive. 


\section{Content}

Preface

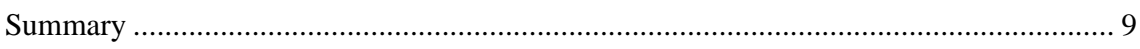

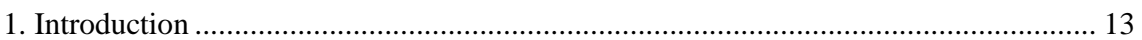

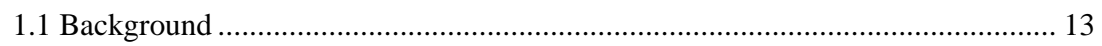

1.2 Energy labelling of domestic appliances ........................................................... 13

1.3 Earlier experiences of energy labelling for household appliances........................ 16

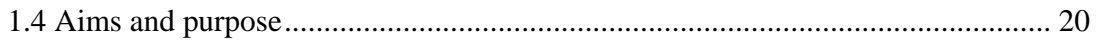

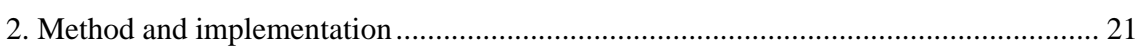

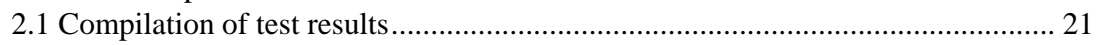

2.2 Interviews with testing personnel and main importers ....................................... 23

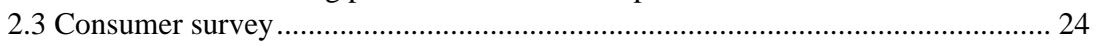

3. Test results and experiences related to energy labelling in the Nordic countries........... 25

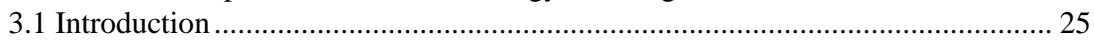

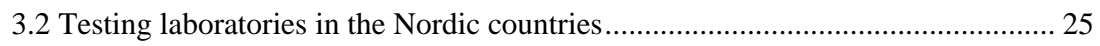

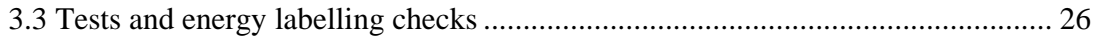

3.4 Can household appliances become more energy efficient? .................................. 37

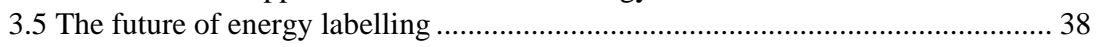

3.6 Standardized test methods ..................................................................................... 39

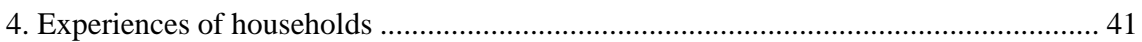

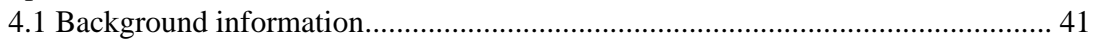

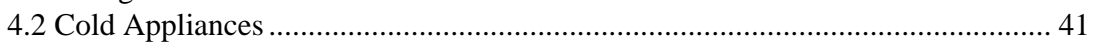

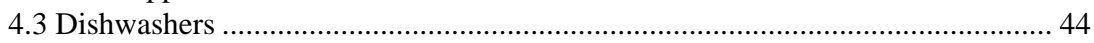

4.4 Ovens (Free-standing electric cookers and built-in ovens)................................. 46

4.5 Washing machines (Washing machines and combined washer-dryers) .................. 47

4.6 Tumble dryers (Combined washer-dryers and tumble dryers) ............................. 50

4.7 Energy labelling ............................................................................................ 52

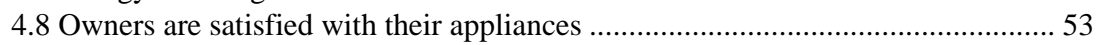

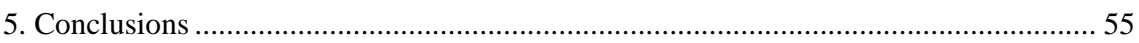

5.1 Household appliances in the Nordic market has changed.................................... 55

5.2 Energy label tests do not correspond to actual use .............................................. 56

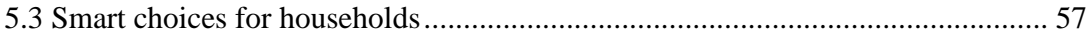

5.4 Has energy labelling had any impact on how appliances are used by households?57

5.5 The Work still to be done ..................................................................................... 58

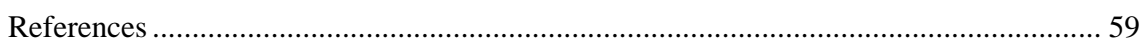

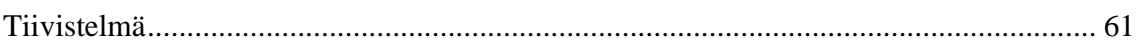

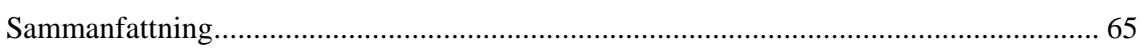

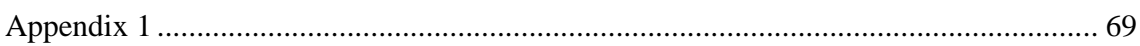

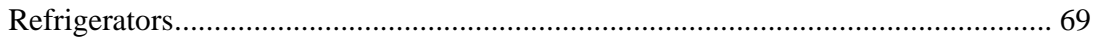

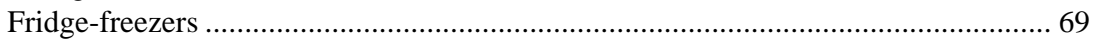

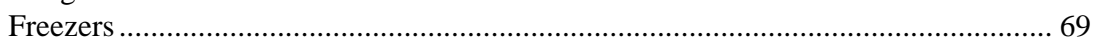

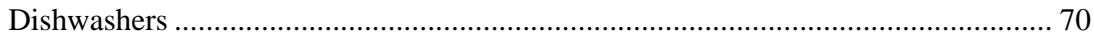

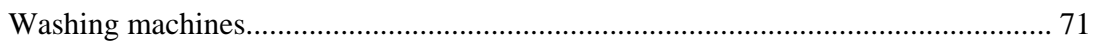

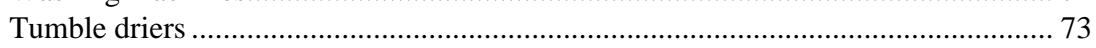

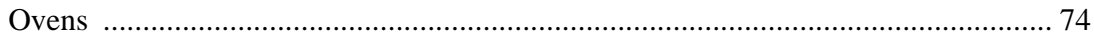





\section{Preface}

The purpose of energy labelling is to provide consumers with information on the energy consumption and other properties of the appliances they use and to help them choose appliances that consume as little energy as possible.

This project has compiled the results of tests run on household appliances and the role of energy labelling in product development. The project also includes a survey carried out by the Finnish Taloustutkimus on the use of the appliances in households. The results of the project can be used to improve the energy-labelling scheme and to support revision of the Energy Labelling Directive.

This project was funded by the Nordic Council of Ministers, Motiva (Finland), the Norwegian Water Resources and Energy Directorate (NVE) (Norway), the Swedish Consumer Agency and the Swedish Energy Agency (STEM) (Sweden).

The project team consisted of the following members:

Anne Korhonen, TTS Research, Finland

Irene Roos, TTS Research, Finland, Project Manager

Harald Throne-Holst, SIFO

(National Institute for Consumer Research), Norway

Heidi Mollan Jensen, SIFO, Norway

Helena Ahlkvist-Johansson, Swedish Energy Agency, Sweden

Gunilla Rosen, Swedish Consumer Agency, Sweden

This report was compiled by TTS Research, Finland. 



\section{Summary}

Energy labelling of household appliances is compulsory throughout the European Union. The purpose of the scheme is to provide consumers with information on the energy consumption and other important properties of the appliances they use and to help them choose appliances that consume as little energy as possible. Energy labelling is currently compulsory for cold appliances (fridges and freezers), washing machines, tumble dryers, combined washer-dryers, dishwashers and ovens.

According to the EU energy labelling rules, tests applied to the measurement of energy efficiency must reflect actual use of the appliances by consumers. In some cases, however, it has emerged that energy labelling has actually impaired the performance of household appliances from the consumer's point of view: washing cycles for dishwashers and washing machines have become longer, the load capacity of washing machines higher and the freezing capacity of freezers lower.

The purpose of the project was to identify changes implemented in household appliances available on the Nordic market since the introduction of the compulsory energy label and to describe the effect of the energy-labelling scheme on the use of the appliances by households. Another purpose was to establish whether households could choose the most energy-efficient appliances on the basis of the energy label information and whether the energy-labelling scheme corresponded to the actual use of the appliances.

This project was based on test results of energy-labelled household appliances gathered in the Nordic countries. Also interviews of people engaged in testing household appliances as well as suppliers of household appliances. These interviews focused on their views on the impact of energy labelling on household appliances. Taloustutkimus Oy conducted an Internet survey in Finland, Norway and Sweden that was aimed at 20to 65-year-old consumers who had bought at least one energy-labelled household appliance - a fridge, freezer, dishwasher, oven, washing machine or tumble dryer. They were asked about their actual use of the household appliances and about their opinions on them. The survey also included questions about energy labelling.

The project showed that during the past ten years of the scheme, household appliances have become more energy-efficient. The change has been most dramatic in the case of cold appliances. Washing machines and dishwashers are also using less energy today. Better insulation in fridges and freezers has resulted in reduced internal volume. Freezers has also a lower freezing capacity than before. In the case of tumble dryers, increasing the energy efficiency has been less easy, but new technology 
may soon solve this problem. Energy labelling for ovens has been in place for too short a time to allow any conclusions about whether the scheme has improved their energy efficiency. However, it is obvious that the energy-efficiency requirements for ovens are quite low as most ovens are already rated $\mathrm{A}$ or $\mathrm{B}$.

Both the testing personnel and the suppliers in the Nordic countries agree that energy labelling has influenced and steered the product development of household appliances. The energy-labelling scheme has accelerated the trend towards larger appliances, which means that the selection of smaller-sized appliances in the market has shrunk, despite the fact that the number of small households in the Nordic countries is on the increase. The energy label requirements are easier to meet with larger appliances. Some of the interviewees among both the testing personnel and the suppliers suspected that energy labelling has in fact resulted in poorer rinsing in washing machines, which could be due to the low water consumption. Energy labelling does not really cover the effectiveness of rinsing, since there is no standardized method to measure this. The heat distribution of ovens cannot be properly tested under the energy-labelling scheme, either, nor are there any methods for measuring the evenness of the heating distribution.

According to the Internet survey, more than $90 \%$ of the households surveyed were satisfied with their appliances, with ovens rated highest on their list and tumble dryers lowest. Most respondents had not noticed that the capacity of cold appliances had become lower or that the freezing times were longer than before. Households reported that their fridges and freezers were full. Their dishwashers were loaded fully and the dishes rinsed before they were put into the dishwasher. The dishwashers were connected to cold-water lines and set at high temperatures. The respondents were satisfied with the cleaning and drying performance of their dishwashers. Nearly half of the respondents felt that the dishwasher cycles were too long. With regard to washing machines, the respondents washed their laundry at lower temperatures and were very satisfied with the results. However, many felt that the cycles were too long. Most respondents did not think that their washing machines rinsed poorly, nor was the extra rinse function used very often.

Energy labelling has had an impact on the product development of household appliances. Today's appliances are energy-efficient and users are satisfied with them; however, the test methods applied to energy labelling do not always correspond to the actual use of the appliances tested. Although the current energy-labelling scheme focuses on saving energy, the appliances must also work properly. Energy labelling helps households to get appliances that save energy, but more savings could still be made in the ways in which the appliances are actually used.

The work on improving the energy-labelling scheme and helping households save energy more efficiently should focus on: 
- Studies on the ways consumers use their household appliances and how such ways affect energy consumption. These can be explored through interviews and by observing household habits related to using the appliances.

- Test methods applied to energy labelling. Test methods should be developed further and modified to correspond with the actual use of the appliances by households. One of the requirements for granting an energy label should be to ensure that the appliance functions properly in everyday life and is designed for all users.

- The information on the energy labels. To help households reduce their energy consumption, the energy labels must be more informative. Measures should be taken to create an energy-labelling scheme that will actually advise consumers on saving energy.

- The information provided by sales personnel. Sales personnel in retail shops must be trained to provide customers with information on how to save energy.

- Development of small, attractive household appliances. Households should have the opportunity to choose their appliances on the basis of their own needs and habits, which is why the selection of small appliances available on the market should be increased. 



\section{Introduction}

\subsection{Background}

Energy labelling of household appliances is compulsory throughout the European Union. The basic idea of energy labelling is that standardised and reliable information about energy consumption and product performance is supplied to consumers to enable them to select and buy efficient technology. The energy consumption indicated on the energy label has been measured under laboratory conditions defined in the test standard. The actual energy consumption depends on the placement and use of the appliance

The intention is to increase consumer awareness of the actual energy use of household appliances through reliable and clear labelling at their point of sale. Compulsory minimum efficiency requirements will encourage producers of household appliances to improve product design with a view to lowering the energy consumption.

Energy labelling is currently compulsory for cold appliances, washing machines, tumble dryers, combined washer-dryers, dishwashers and ovens.

According to the EU energy labelling rules, tests applied to measure energy efficiency must reflect the actual normal use of the appliances by consumers. Nordic bodies specializing in testing household appliances have years of relevant experience, and their tests have shown that energy labelling has in some cases actually impaired the performance of household appliances from the consumer's point of view:

- Washing machines and dishwashers have longer cycles;

- Full loads in washing machines have increased;

- Freezers have lower storage capacity for foodstuffs.

\subsection{Energy labelling of domestic appliances}

Energy labelling applies to all appliances and should show both good and bad alternatives. The level of energy efficiency of a model is shown on a scale from A, green colour and low consumption, to G, red colour and high consumption. For fridges and freezers there are also energy classes $\mathrm{A}+$ and $\mathrm{A}++$, where $\mathrm{A}++$ consumes the least energy. The data strip contains information specific to each model and is placed on all appliances of the same model. 
Each of the Nordic countries is responsible for organizing and conducting spot checks to ensure that the information provided by local suppliers for energy labels is correct.

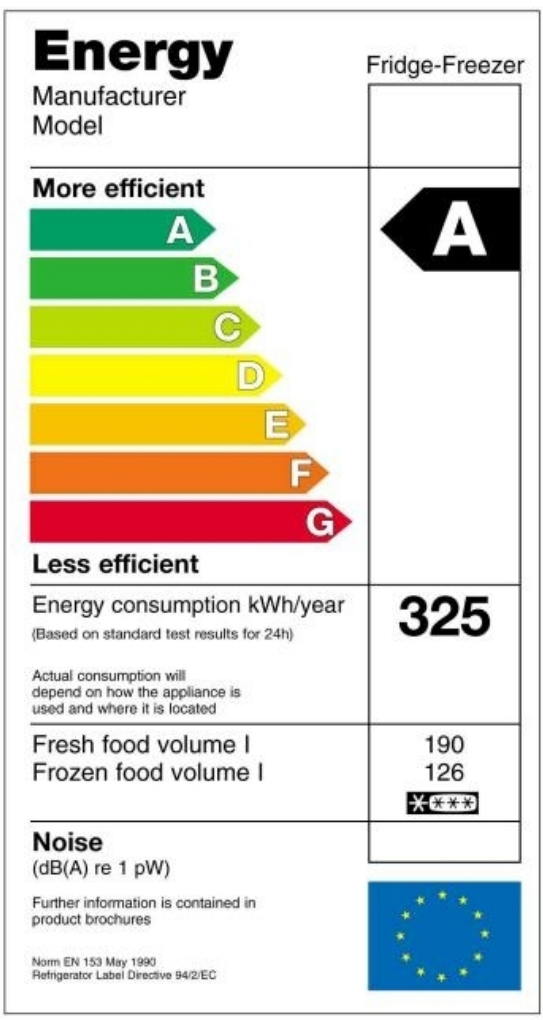

Figure 1 Energy label.

\subsubsection{Refrigerators, freezers and their combinations (cold appliances)}

Energy labelling of household refrigerating appliances was introduced in 1995 (Directives 92/75/EC and 94/2/EC) and minimum efficiency requirements in 1996 (Directive 96/57/EC).

The energy label for a cold appliance always indicates the energy efficiency class, annual electricity consumption in kilowatt hours (kWh) and noise level (optional). In addition, the product information (sales brochures) on a cold appliance must state the freezing capacity of the appliance and the length of the temperature rise period, for example.

It is important to ensure that comparison tests on cold appliances are carried out within category at a time. If an appliance contains several compartments, the volume of each compartment is indicated on the energy label. For example, a fridge with a one-star freezing compartment must not be compared against a fridge with a three-star freezing compartment.

The energy efficiency rating of cold appliances is based on the 1992 level of energy consumption; since 1992, the energy consumption of appliances has dropped by as much as one half. For this reason, the Euro- 
pean Commission adopted an amendment to the Directive in 2003, which introduced energy classes $\mathrm{A}+$ and $\mathrm{A}++$ at the beginning of 2005. Cold appliances rated $\mathrm{D}$ or lower have already practically disappeared from the market altogether.

\subsubsection{Dishwashers}

The energy label of dishwashers was introduced in 1999 (directives 1999/9/EC, 97/17 EC and 92/75/EEC ).

The energy label for dishwashers indicates the energy class rating, the consumption of electricity and water during the basic cycle, and the cleaning and drying performance. Electricity consumption is measured for an appliance that has been connected to a cold-water line $\left(+15^{\circ} \mathrm{C} \pm\right.$ $2^{\circ} \mathrm{C}$ ) and set to the basic cycle indicated by the manufacturer. The cleaning and drying performance of the dishwasher are measured for the same basic cycle, and the results are given on the scale of A to G. While different brands of dishwashers have different names for the basic cycle, the cycle typically consists of a cold initial rinse, cleaning, two further rinses and drying. The number of place settings that the dishwasher has been designed for is also indicated on the energy label. Indicating the noise level is optional.

\subsubsection{Washing machines and tumble dryers}

The energy label of household washing machines was introduced in 1996 (directives 96/89/EC, 95/12/EC and 92/75/EEC) and for tumble dryers (directives 95/13/EC and 92/75/EEC) in 1996.

The energy label for washing machines indicates the energy class rating, the consumption of electricity and water during the $60^{\circ} \mathrm{C}$ cotton cycle, the washing and spin-drying performance and the load capacity. Noise levels are given separately for the washing phase and the spindrying phase. Indicating the noise levels is optional.

The energy label for tumble dryers indicates the energy class rating, the electricity consumption during the cotton cupboard-dry cycle and the load capacity. Indicating the noise level is optional. The information on the energy label is based on drying cotton laundry with $60 \%$ residual moisture content.

\subsubsection{Ovens}

Energy labelling for electric ovens was introduced in 2003 (Directives 92/75/EEC and 2002/40/EC). Energy labels are given for both freestanding ovens and for ovens integrated into kitchen units. The energy label indicates the energy class rating, electricity consumption, internal 
volume and size. The internal volume is given in litres, and the size in one of three different sizes. Indicating the noise level is optional.

The energy efficiency is determined on the basis of a 'brick test', where a wet insulation brick is heated to $55^{\circ} \mathrm{C}$ (EN 50304, 2001) and the length of the heating period and electricity consumption are measured.

\subsection{Earlier experiences of energy labelling for household appliances}

\subsubsection{Optimizing energy efficiency conditions for household appliances}

The EU project 'Optimizing energy efficiency conditions for household appliances' was carried out in five EU countries (Finland, France, Germany, Italy and the Netherlands) in 1998-1999. One aim of the study was to to determine typical problems encountered in using energy- and environment-saving dishwashers and washing machines.

The most frequent problems in dishwashing were outlined as follows:

- Dishware has stains after dishwashing

- Dishware gets a grey coating during dishwashing

- White films on dishes

- Dishware seems to be poorly rinsed

- Dishware doesn't dry in the dishwasher

- Dishwasher smells

- Glass corrosion

The most frequent problems in washing were listed as:

- Particle dust on the textiles and clothes (white dust)

- Textile and clothes have gone grey

- Textiles and clothes have stains

- Detergent is not rinsed out during the washing process

- Detergent residues remain in the dispenser (Humala 1999).

\subsubsection{Revision of energy labelling \& targets washing machines}

The SAVE II study "Revision of energy labelling \& targets washing machines (clothes)" aimed at providing factual and analytical support for EU policy action in the field of washing machines. In 1998 the average energy consumption of a washing machine at a $60^{\circ} \mathrm{C}$ cotton cycle was 0.24 $\mathrm{kWh} / \mathrm{kg}$. The most frequently used wash cycles were the $40^{\circ} \mathrm{C}$ cotton programme and the $60^{\circ} \mathrm{C}$ cotton cycle (25\%). In total $66 \%$ of washes were washed using the $30^{\circ} \mathrm{C}$ and $40^{\circ} \mathrm{C}$ cycles.

The recommendations of the study included 
- To increase the prominence of the spin performance indication on the energy label

- To define actual consumer behaviour

- To identify an acceptable level of rinsing performance from the viewpoint of health and fabric care

- To promote the correct dosage of detergents and the lowering of wash temperatures and the correct load size to assist the consumer (Novem 2001).

\subsubsection{An investigation of domestic laundry in Europe}

The project: An investigation of domestic laundry in Europe researched washing habits in four countries (Greece, the Netherlands, Norway and Spain). The project was financed by the consumer policy programme of the EU.

A number of findings from the three different main studies (survey, laundry performance and hygienic quality) were grouped into four categories. These categories were chosen so that they related to hygiene and cleaning performance. The categories were:

- Laundering practices

- Attitudes

- Detergents used

- Temperature used and the frequency of doing laundry in the households.

The laundry patterns varied greatly from country to country. Spain showed the greatest differences in its washing practices in this investigation. This pertains to both performance and hygiene, as well as to laundry habits. Consumers in Spain use the lowest washing temperature. For example the Spanish wash their bed sheets using cold water or at $30^{\circ} \mathrm{C}$. The most usual temperature in Greece, the Netherlands and Norway is $60^{\circ} \mathrm{C}$ (Arild et al. 2003).

\subsubsection{Effects of energy reduction on washing machines}

In his presentation for the EEDAL'03, Paul Terpstra examined the impact of energy labelling on how households used their washing machines. Energy reduction is inevitably linked to lower wash temperatures and water consumption. However, this will also deteriorate the washing performance.

The household system is dynamic and it will respond to interventions that influence the level of performance, e.g. in the following ways:

- Increasing the washing frequency 
- Using a higher detergent dosage

- Increasing the use of chemicals such as pretreaters and boosters.

When textiles are washed at lower temperatures the hygienic quality of the laundry will also be reduced (Terpstra 2003).

\subsubsection{Consumer behaviour in washing}

A survey on consumer behaviour in washing was conducted in Germany in 2004 and 2005. Approximately 6000 questionnaires were evaluated. Survey items comprised:

- Satisfaction with washing result

- General washing habits

- Detergent use

About $60 \%$ of the respondents were always satisfied with the wash result. Only a small percentage of respondents were frequently dissatisfied with the wash result or didn't care if the wash result didn't fully meet expectations.

Almost $40 \%$ said that they sort the items for washing by colour and wash dark items separately. About $30 \%$ said that they wash items in line with the care symbols on the garment. Almost 30\% normally washed at $60^{\circ} \mathrm{C}$ and approximately $60 \%$ normally did a wash at 30 or $40^{\circ} \mathrm{C}$. Over $10 \%$ chose the temperature depending on the degree of dirt or sometimes did a wash at $90^{\circ} \mathrm{C}$. Very few people regularly used the pre-wash facility.

The survey research was completed by an Internet-based calculator to assess consumption data and washing costs. According to the Internet survey the average washing temperature was $46^{\circ} \mathrm{C}$ and the most common washing temperature was $40^{\circ} \mathrm{C}$ (Elschenbroich \& Gördeler 2006).

\subsubsection{Amendments to energy labels of washing machines}

The Market Transformation Programme (MTP) aims to reduce the environmental impact of products throughout their life cycle. The MTP has suggested changes in the energy labels of washing machines. The reason for the changes proposed by the MTP is that consumers do not generally use washing machines in the same way as they are tested for the energy label. Surveys of consumers show that the $40^{\circ} \mathrm{C}$ cotton programme is the most commonly used and most often the drum is only partly filled.

In $200486 \%$ of washing machines sold in the UK were categorised as energy efficiency class A. The energy label no longer provides a market incentive for development of a more energy-efficient washing machine. The MTP proposes to continue to base the energy label around the $60^{\circ} \mathrm{C}$ cotton test with a maximum load and to include the rating of cleaning 
performance and energy consumption for the $40^{\circ} \mathrm{C}$ cotton programme with a full load.

In addition to the energy efficiency rating the ability of the washing machine to reduce energy consumption when the drum is only partly loaded should be taken into account. The energy label should include the programme duration, minimum temperature requirements for the $60^{\circ} \mathrm{C}$ programme, and standby energy consumption (Owen 2004).

\subsubsection{Ten years of energy labelling of domestic appliances 1995-2005}

The Swedish Consumer Agency (Konsumentverket) and the Swedish Energy Agency (Energimyndigheten) have accumulated 10 years' experience from work with compulsory energy labelling. The energy-labelling scheme has had the intended effect both when it comes to the available choices and to the sales of more energy-saving household appliances.

Volumes of refrigerators and freezers have decreased as a result of increased insulation, whereas washing machines and tumble dryers hold more and more laundry, according to the manufacturers' own information, which means that the energy consumption goes down per kilo of laundry. Before energy labelling was introduced, the most common capacity was three and a half kilos and today there are several models that, according to the manufacturers, hold seven or eight kilos per cycle. This development, however, is completely opposite to many people's habits and behaviour. Weighing laundry at Testlab has shown that on average two and half kilos are washed per cycle. Furthermore, most households in Sweden comprise one or two people.

Furthermore, the Energy Label lacks information that is important to the consumers of today, for example how well ovens bake and heat up or the rinsing performance of washing machines.

The sales statistics for the energy-labelled domestic appliances show that most appliances are sold in energy class A, with the exception of tumble dryers where energy class $C$ is still the most common (Energimyndigheten 2006).

\subsubsection{Energy consumption refrigeration appliances in normal operating conditions}

The Home Economics Department of the TTS Institute (TTS Research since 2007) studied the energy consumption of refrigeration equipment under normal operating conditions. The study measured the energy consumption of approximately 60 energy-labelled refrigeration units in 40 households.

The measured energy consumption of the refrigeration units showed considerable variation. Converted into annual consumption, the range was 63 to $956 \mathrm{kWh}$ per year. Half of the units were within the 15\% varia- 
tion allowed in the test standard (EN 153). Approximately 25\% of the units consumed more than $15 \%$ less energy than indicated on the energy label, and approximately $20 \%$ of the units consumed more than $15 \%$ more energy than indicated on the energy label. The energy consumption of the refrigeration units was, on average, $1 \%$ lower than indicated on the energy label.

The ambient temperature in the location of the refrigeration unit was the most important factor affecting energy consumption. The units that consumed the least as compared with the energy label were placed in cool rooms.

The energy consumption of refrigeration appliances varies a great deal, but the TTS survey suggests that the energy consumption indicated on the energy label, on average, corresponds quite well to the actual consumption in a home in winter (Korhonen 2006).

\subsection{Aims and purpose}

The aims of the project were to:

- Illustrate changes implemented in household appliances in the Nordic market since the introduction of the compulsory energy label;

- Examine whether the energy labels corresponded to the actual use of the appliances, as required by the EU rules on energy labelling;

- Assess the ability of households to make energy-efficient choices on the basis of the energy label information;

- Assess the impact of energy labelling on the actual use of the appliances by households. 


\section{Method and implementation}

\subsection{Compilation of test results}

This report was compiled from the results of tests on household appliances conducted in Denmark, Finland, Norway and Sweden. The selection of the appliances tested did not reflect the actual situation on the household appliances market, as they represented only a small sample of the appliances available to consumers and were selected for varying reasons. Some of the tests were performed to check the data indicated on the energy labels and others were comparison surveys of appliances similar in price, size or functions, for example.

\subsubsection{Cold appliances}

Energy labelling for cold appliances was introduced in 1995. The test results were gathered from tests carried out in 2000-2005, in addition to those carried out in the early years of the energy-labelling scheme in 1995 and 1996. Tests results gathered in Sweden were excluded, as they could not be allocated to specific years.

The appliances were divided into three main groups: fridges, fridgefreezers and freezers. The following data were gathered from the test results:

- Usable volume, 1

- Energy consumption, kWh/year

- Energy efficiency class

In addition, the 24-hour consumption of energy per 100 litres was calculated.

\subsubsection{Dishwashers}

Energy labels have been awarded for dishwashers since 1999. They indicate energy consumption for a basic cycle of a dishwasher connected to a cold-water line (kWh per cycle). The test results were gathered from tests carried out in 1998-2005.

The following data were gathered from the test results:

- Load, settings

- Washing temperature (set)

- Total energy consumption, kWh 
- Total water consumption, 1

- Time

- Energy efficiency class

- Washing performance class

- Drying efficiency class

In addition, the energy and water consumption was calculated on the basis of the appliance's capacity given in terms of place settings.

\subsubsection{Washing machines}

Energy labelling for washing machines was introduced in 1996. Their energy consumption stated on the energy label is based on the $60^{\circ} \mathrm{C}$ cotton cycle (kWh per cycle). Because the SAVE WET study had been based on test results obtained in 1999 (in the Nordic countries), test results for this report were from 2000-2005. For comparison, the appliances tested in 1996 were included.

The following data were gathered from the energy-labelling scheme test results:

- Load, kg

- Spin speed

- Washing temperature, max

- Total energy consumption, kWh

- Total water consumption, l

- Water consumption, $\mathrm{l} / \mathrm{kg}$

- Time

- Moisture content after spinning, \%

- Energy efficiency class

- Washing performance class

- Spin drying performance class

In addition, the consumption of energy and water per one kilogramme of laundry was calculated.

\subsubsection{Tumble dryers}

Energy labelling for tumble dryers was introduced in 1996. The energy consumption indicated on the energy labels for tumble dryers is based on the cotton cupboard-dry cycle ( $\mathrm{kWh}$ per cycle). The test results were gathered from tests carried out in 1999-2005.

The following data were gathered from the energy-labelling scheme test results:

- Load, kg 
- Total energy consumption, kWh

- Time

- Energy efficiency class

In addition, the consumption of energy and water per kilogramme of laundry was calculated.

\subsubsection{Ovens}

Energy labelling for ovens was introduced in 2003. The test results were gathered from tests carried out in 2003-2005.

The following data were gathered from the test results:

- Usable volume, 1

- Usable surface area, $\mathrm{cm}^{2}$

- Energy consumption, kWh (conventional heating, forced air)

- Energy efficiency class

\subsection{Interviews with testing personnel and main importers}

A total of 11 interviews were carried out among testing personnel in all Nordic countries except Iceland. Each interview focused on a specific product group, and some of the interviewees could also respond to questions about more than one product group (Table 1). The interviews were mostly conducted over the telephone or in person. The interviewees could also respond in writing and were given an opportunity to expand or elaborate their responses later on. The responses obtained were consistent with the results of the technical tests and customer feedback.

Table 1 Test laboratories where the interviews were carried out.

\begin{tabular}{lccccc}
\hline & Cold appliances & Dishwashers & Ovens & Washing machines & Tumble dryers \\
\hline $\begin{array}{l}\text { Danish Technological } \\
\text { Institute, Denmark }\end{array}$ & $\mathrm{x}$ & & $\mathrm{x}$ & $\mathrm{x}$ \\
TTS Research, Finland & $\mathrm{x}$ & $\mathrm{x}$ & $\mathrm{x}$ & $\mathrm{x}$ & $\mathrm{x}$ \\
SIFO, Norway & $\mathrm{x}$ & $\mathrm{x}$ & $\mathrm{x}$ & & \\
Energy Agency, Sweden & $\mathrm{x}$ & $\mathrm{x}$ & $\mathrm{x}$ & \\
\hline
\end{tabular}

Four interviews were carried out with the following Nordic suppliers: Electrolux, BHS, Helkama and Upo. The interviews were conducted over the telephone. All except Helkama had a Nordic sales organization to coordinate their sales in all Nordic countries. Each operated in a similar market and followed a similar marketing policy, with slight differences in emphasis on different issues in the Nordic countries. Rather than focusing on differences between household appliances, the questions asked at the 
interviews were about the impact of energy labelling on household appliances in general and possible ways to develop the energy-labelling system.

\subsection{Consumer survey}

This part of the research was conducted by Taloustutkimus Oy in Finland using an Internet survey in three countries: Finland, Sweden and Norway.

The target group of the research was 20- to 65-year-old consumers who participate in the purchase decisions of household appliances and who have bought at least one of the studied household appliances since the introduction of energy labelling (Table 2). The household appliances studied in this research were cold appliances (refrigerators or fridge coolers, fridge/freezers or other combinations and freezers), dishwashers, ovens (electric cookers and built-in ovens), washing machines (washing machines and combined washer-dryers) and tumble dryers (tumble dryers and combined washer-dryers). The aim was to reach 200 people in each of Finland, Sweden and Norway.

- In Finland the research was conducted between 11 and 13 April 2007. Out of 604 invited panellists 233 people completed the questionnaire.

- In Sweden the research was conducted between 13 and 16 April 2007. Out of 602 invited panellists 206 people completed the questionnaire.

- In Norway the research was conducted between 10 and 12 April 2007. Out of 794 invited panellists 215 people completed the questionnaire.

The participants who had bought at least one of the household appliances since energy labelling had been introduced for the particular appliance type were asked statements about the use of the appliance, about the appliance itself and about general satisfaction with the appliance. Some household appliances also had some additional questions. The participants were also asked some statements about the energy labelling in the purchase situation of household appliances. The respondents were asked to assess how well the statements describe their use of cold appliances (scale 5-1, 5=very well and $1=$ very badly), and how much they agree or disagree (scale $5-1,5=$ totally agree, $1=$ totally disagree) with the statements about the appliances.

Table 2.The studied household appliances and energy labelling.

\begin{tabular}{lll}
\hline & energy labelling since & bought a household appliance \\
\hline Cold appliances & 1995 & last 11 years \\
Washing machines & 1996 & last 11 years. \\
Tumble dryers & 1996 & last 11 years. \\
Dishwashers & 1999 & last 7 years. \\
Electric cookers and ovens & 2003 & last 3 years \\
\hline
\end{tabular}




\section{Test results and experiences related to energy labelling in the Nordic countries}

\subsection{Introduction}

This project was based on test results of energy-labelled household appliances gathered in the Nordic countries. Testers and suppliers of household appliances were interviewed, focusing on their views on the impact of energy labelling on household appliances.

\subsection{Testing laboratories in the Nordic countries}

All the Nordic countries except Iceland maintain publicly funded laboratories for testing consumer products. In recent years, however, these laboratories have have undergone major changes in their work. In spring 2005, the Danish National Consumer Agency (Forbrugerstyrelsen) was closed down and part of the laboratory's work on testing household appliances was transferred to the Danish Technological Institute.

The Swedish Consumer Agency (Konsumentverket) was relocated to Karlstad and the testing of household appliances was transferred to the Energy Agency at the beginning of 2006. The Energy Agency's test laboratory conducts independent tests on the performance of household appliances, in accordance with current European and international standards.

In Finland, one of the TTS Research units focuses on testing household appliances and other household equipment, e.g. kitchen tools and compost containers. TTS's work is partly funded through a state subsidy for the Consumer Agency; the rest of TTS's work is self-financed. TTS has limited resources for participation in standardization or development of test methods. Its laboratory has not been accredited for tests on household appliances, and many of the tests it conducts are largely adapted to Finnish circumstances.

The Norwegian National Institute for Consumer Research (Statens institutt for forbruksforskning, SIFO) has a product testing department for testing textiles, detergents and household appliances. The laboratory has been accredited mainly for methods related to testing textiles and laundry washing. Commissioned by the Norwegian Water Resources and Energy Directorate (NVE), it also carries out checks on the energy labelling of household appliances. SIFO participates in standardization work both 
within the textile industry and within workgroups for household appliances. NEMKO, too, checks the energy labelling of certain household products.

\subsection{Tests and energy labelling checks}

There have been fewer tests on household appliances in recent years at the Nordic laboratories than before. Extensive tests encompassing several products and designed to provide consumers with information on the current supply of appliances on the market are carried out from time to time. Laboratories themselves, however, find it difficult to conduct commissioned tests and energy-labelling checks separately, as these often overlap. Some of the tests are carried out on behalf of manufacturers, others to verify the energy labelling on the appliances and the rest to make the results public for consumers. This means that the range of products tested varies considerably and the laboratories are not always allowed to decide themselves whether the results will be published.

\subsubsection{Cold appliances}

Energy labelling has resulted in the manufacture of fridges and freezers that use far less energy than before. Cool appliances are now larger in size, and small fridges and freezers have disappeared from the market. More and more freezers are 'no-frost' models (i.e. equipped with automatic defrosting), and many have shelves rather than boxes for foodstuffs. Many fridge models are equipped with a $0^{\circ} \mathrm{C}$ zone, electronic controls and a 'supercool' function. Electronic temperature control and a thermometer on the outside of the appliance help users to set the right temperature, and error signals alert them to problem situations.

Insulation of fridges and freezers is thicker today; their volume, on the other hand, is proportionately lower, particularly in the case of freezers, which is why many manufacturers produce models that are wider than the standard 60 centimetres.

When cold appliances are checked for energy labelling information, the door of the appliance remains closed throughout the test, while the room temperature is $25^{\circ} \mathrm{C}$, which is slightly higher than in the kitchens of most households. The energy consumption indicated in the product information is presumed to correspond to the average energy consumption by households.

\section{Fridges are becoming more and more energy-efficient}

The test results for fridges were gathered from tests carried out in 2000-2005. The tests covered a total of 68 appliances (between 6 and 17 per year). Because the types and volumes of the appliances tested 
varied from one year to another, no clear trend could be seen in energy consumption (Appendix 1, Table 4). In 2002, for example, the fridges tested had freezing compartments, while all the other fridges tested did not. The energy efficiency ratings for the appliances tested, however, showed a trend towards increasingly energy-efficient appliances (Figure 2).

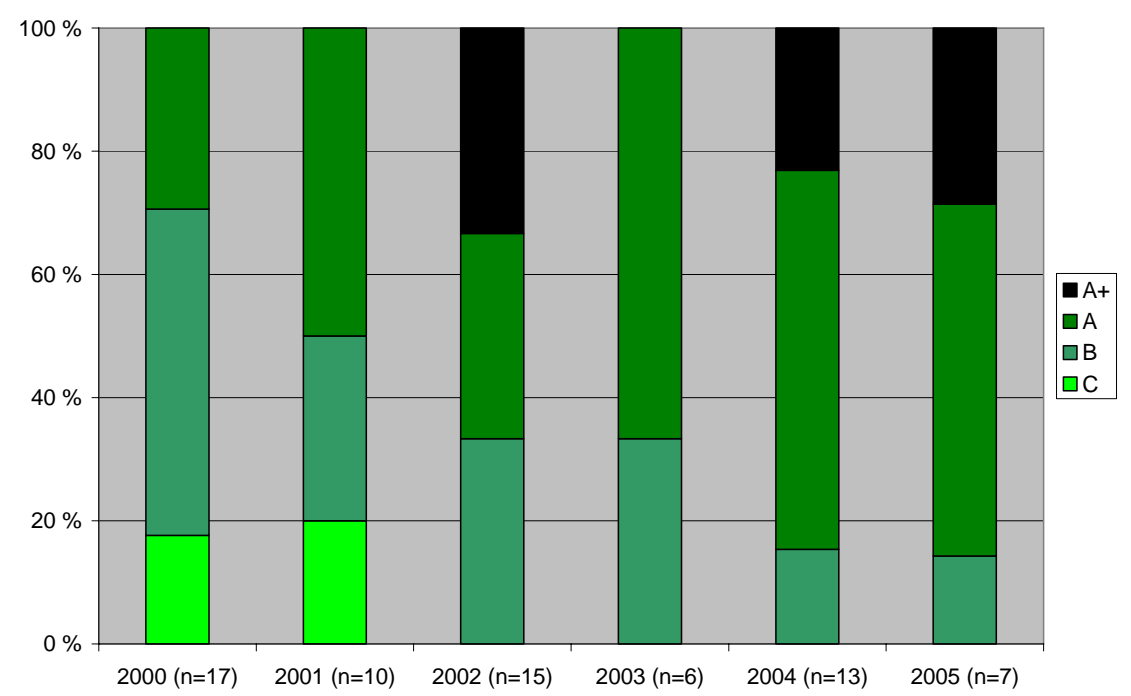

Figure 2 Distribution of fridges tested in the Nordic countries in 2000-2005 into energy efficiency classes.

\section{Class B is the lowest rating for today's fridge-freezers}

The tests covered a total of 93 appliances (between 9 and 32 per year). Compared to fridge-freezers tested in 1995, today's appliances consume an average of $23-40 \%$ less electricity. The average electricity consumption of fridge-freezers tested in 1995 was about $1.5 \mathrm{kWh}$ per 24 hours and about $0.5 \mathrm{kWh}$ per 100 litres per 24 hours. The average electricity consumption of appliances tested in 2004-2005 was about $1 \mathrm{kWh}$ per 24 hours and about $0.3 \mathrm{kWh}$ per 100 litres per 24 hours. (Appendix 1, Tables 8 \& 9)

The energy efficiency of the fridge-freezers tested has increased rapidly. The appliances tested in 1995 were rated B-F for their energy efficiency, mostly B. In 2004-2005, the poorest performance among fridgefreezers fell within class B (Figure 3). 


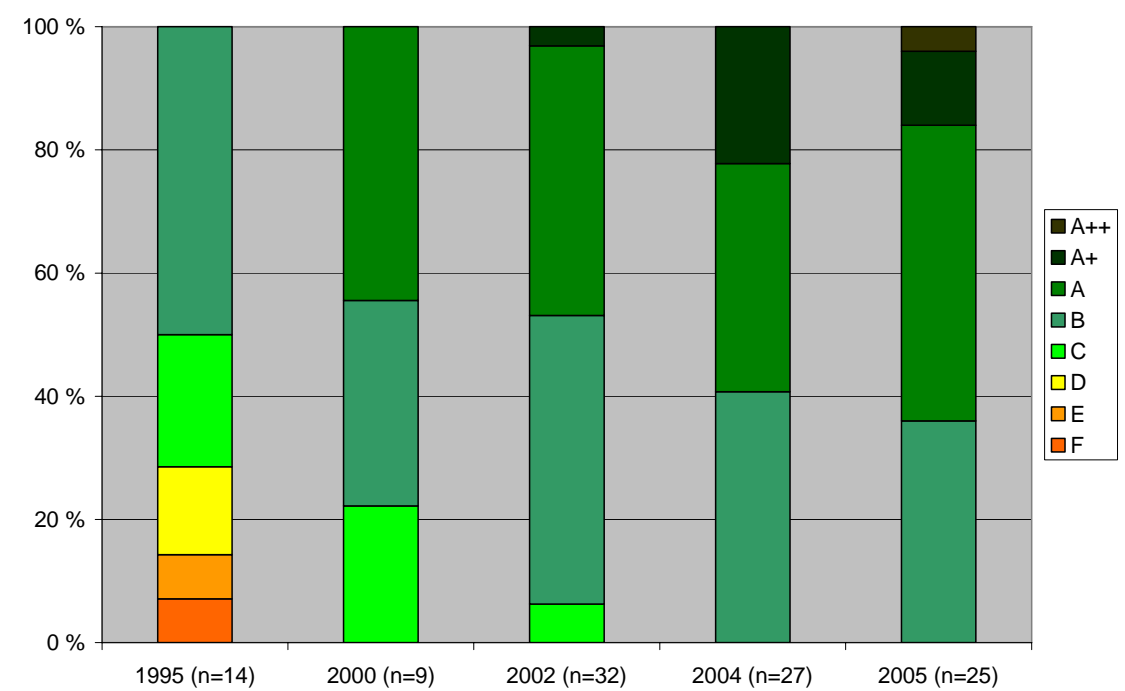

Figure 3 Distribution of fridge-freezers tested in the Nordic countries in 1995 and 20002005 into energy efficiency classes.

Rapid increase in the energy efficiency of freezers

The test results for freezers were gathered from tests carried out in 2003-2005. The tests covered a total of 30 appliances. Compared to freezers tested in 1996, today's appliances consume an average of 5$50 \%$ less electricity. The volumes of the freezers varied from one year to another, however. The average electricity consumption of freezers tested in 1996 was about $1.2 \mathrm{kWh}$ per 24 hours and about $0.51 \mathrm{kWh}$ per 100 litres per 24 hours. The average internal volume was 245 litres. The average electricity consumption of freezers tested in 2003-2005 was about $0.6-1 \mathrm{kWh}$ per 24 hours and about $0.26-0.49 \mathrm{kWh}$ per 100 litres per 24 hours; the average internal volume was 178-236 litres. (Appendix 1 , Tables $11 \& 12$ )

The energy efficiency of the freezers tested has increased rapidly. Appliances tested in 1996 had distributed fairly evenly between energy efficiency classes A-G. In 2004-2005, the poorest performance among fridge-freezers fell within class B (Figure 4). 


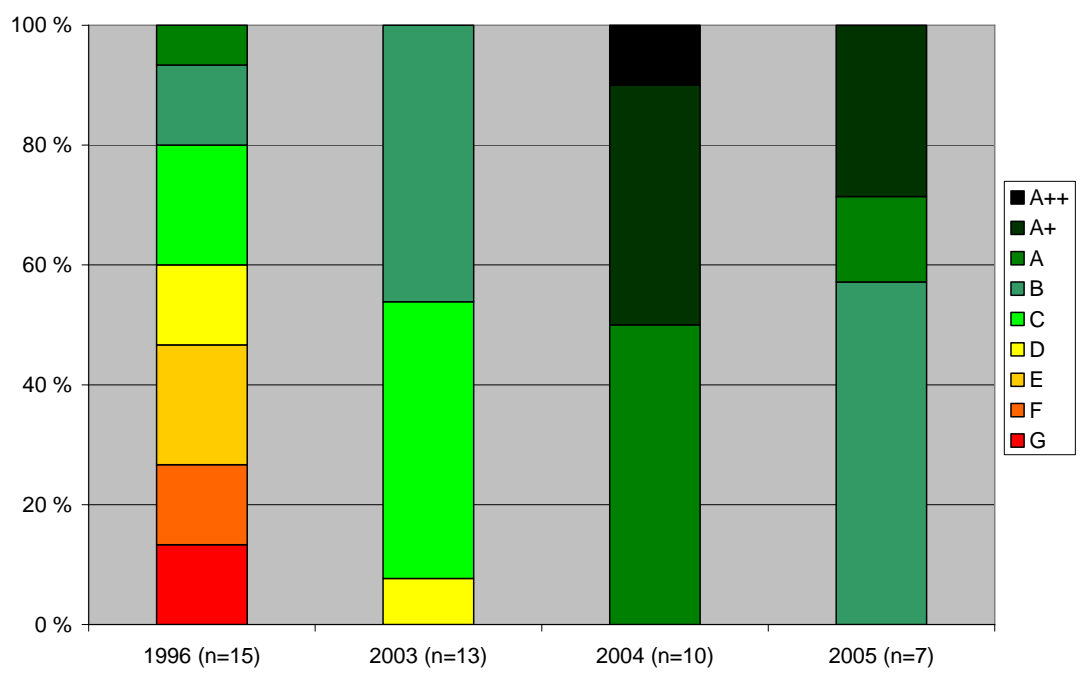

Figure 4 Distribution of freezers tested in the Nordic countries in 2003-2005 into energy efficiency classes.

Comments from testing personnel and suppliers:

"Because compressors are less powerful today, upright A+-rated freezers have poorer freezing capacity. Smaller compressors mean lower power consumption."

"Few customers complain about their cold appliances; most comments are about the reduced volume of the appliances."

"The appliances have become more sensitive to environmental temperatures. According to households, there have been problems in the summer. When a fridge is loaded with warm foods, it takes some time for it to cool down to the correct internal temperature."

\subsubsection{Dishwashers}

At the end of the 1970s, dishwashers used 60-70 litres of water per cycle as opposed to today's 12-15 litres per cycle. Nevertheless, the results of the washing up are good, despite the lower consumption of water and energy. Interviews with testing personnel showed that many households, for example, suspect that today's dishwashers rinse less thoroughly than earlier models.

On the other hand, people's dishwashing habits have also changed. Dishwashers are now filled with a larger variety of dishes and utensils, and fewer dishwashers are left only half full when they are switched on. Much of the dishwasher's load today consists of mugs and glasses, which means that the top tray fills up sooner than the bottom tray. 
Dishwasher cycles are now twice as long as before.

The tests covered a total of 88 appliances (between 5 and 19 appliances per year). According to the test results for dishwashers, water and electricity consumption have decreased, washing cycles have become longer and energy efficiency ratings are higher (Figures 5-7; Appendix 1, Tables 15-18). Between 1994 and 2005, water consumption has dropped from 24 litres to 14 litres (Appendix 1, Table 15).

Meanwhile, the washing cycles have become about twice as long, from 1 hour to 2-2.5 hours (Appendix 1, Table 19). Longer cycles during test washes are partly due to the fact that dishwashers in Finland were connected to a hot-water line for the test situation, which is very common in households; for the energy-labelling test method, however, the dishwasher should actually be connected to a cold-water line. Tests conducted at TTS show that this makes an energy-labelled cycle 20-30 minutes longer.

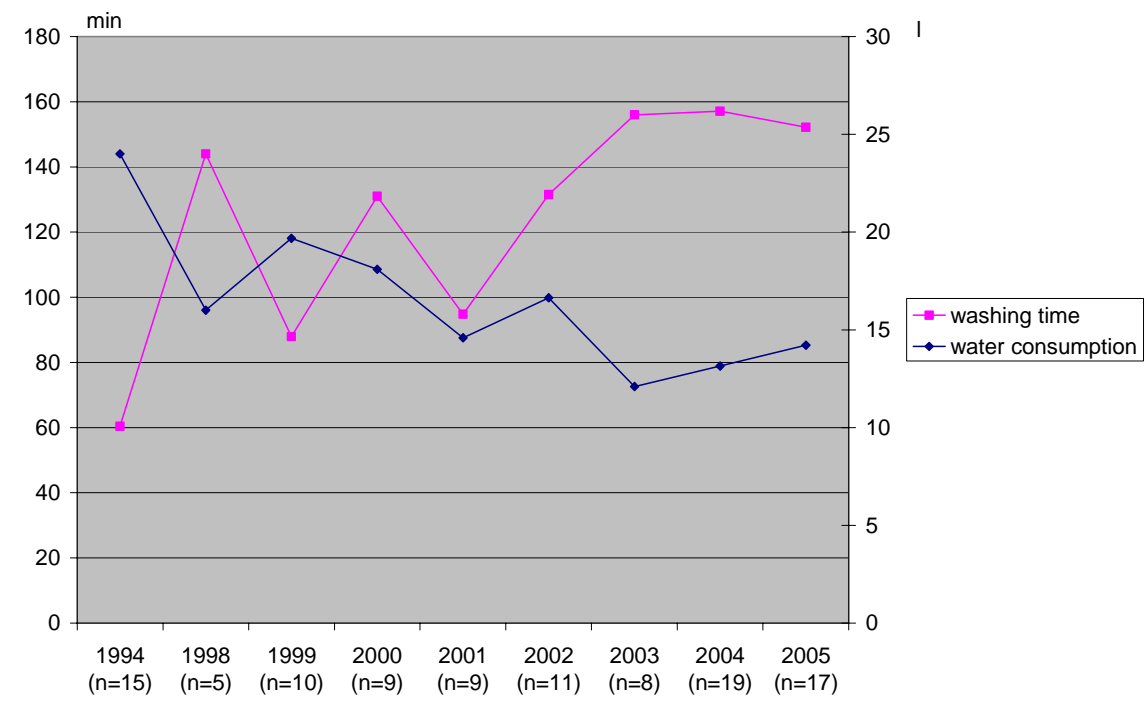

Figure 5 Distribution of dishwashers tested in the Nordic countries in 1998-2005 into energy efficiency classes. 


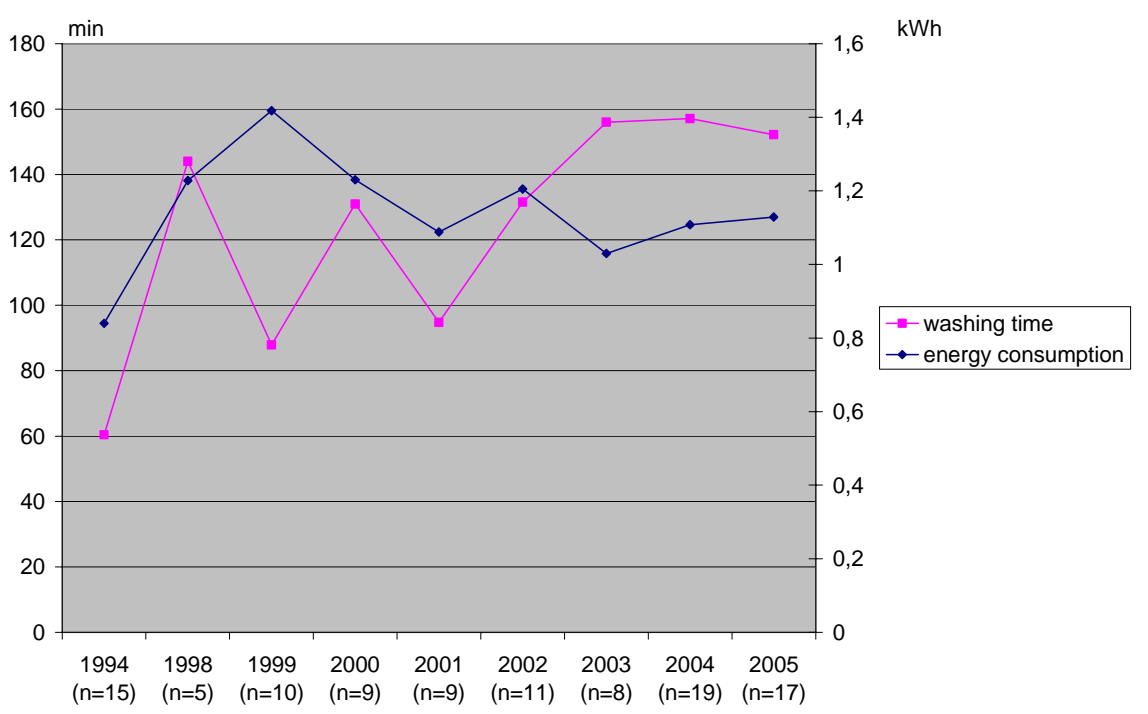

Figure 6 Distribution of dishwashers tested in the Nordic countries in 1998-2005 into energy efficiency classes.

\section{Problems from low water consumption?}

It was often pointed out at the interviews that the filters of today's watersaving dishwashers needed frequent cleaning to prevent food remaining on the dishes. The interviewees suspected that many people would set the water temperature higher or rinse the dishes before putting them into the dishwasher, in which case the amount of rinsing water would be higher than the amount consumed by the dishwasher.

Dishwasher manufacturers may decide themselves which cycles will bear energy labels, but these cycles are not indicated to consumers. In the testing personnel's view, it is quite possible that people believe that the energy label on a dishwasher applies to all cycles.

Because of differences in the capacities of the appliances tested, test results obtained in consecutive years may deviate from general trends. In some years, smaller dishwashers designed for 8 place settings or even table-top dishwashers for 3-6 place settings have been tested in addition to appliances for 12 place settings, although they are less energy-efficient than the latter (Appendix 1, Table 13). However, the trend has been similar to that related to cold appliances: dishwashers are becoming more and more energy-efficient (Figure 7). 


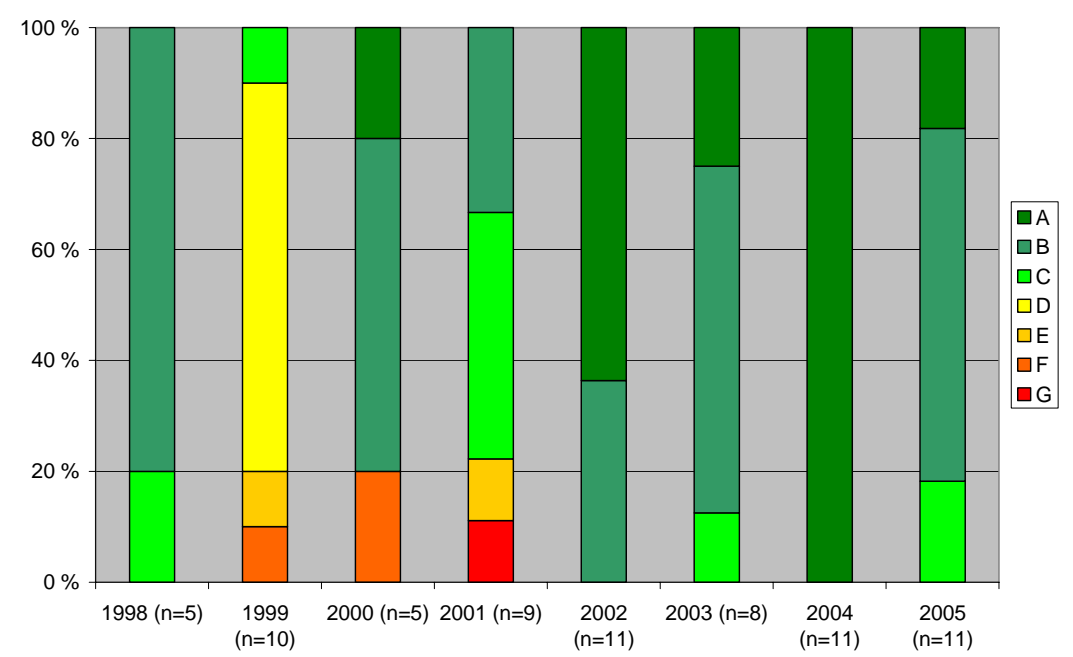

Figure 7 Distribution of dishwashers tested in the Nordic countries in 1998-2005 into energy efficiency classes.

It emerged at the interviews that energy labelling had resulted in less flexible practices of loading the dishwasher, as the low amount of water is more demanding on the placement of the load. If there are lots of mugs and glasses to wash, for instance, the bottom tray usually remains relatively empty. This is probably due to the fact that the trays are more spacious to ensure lower water consumption and to allow the rinse water to run more freely.

Comments from testing personnel and suppliers:

"People find the long cycles hard to accept. When they buy an energylabelled dishwasher they think that all the cycles are energy-efficient, but the energy label usually refers to the most inconvenient cycle."

"As a rule, the washing performance is good, considering the low amount of water."

"The trays must be designed adequately enough so that they can be adjusted for as large loads as possible.”

\subsubsection{Washing machines}

Today's washing machines have long cycles; overall, clothes go through longer washing cycles now than they did 10 or 15 years ago. Because of the low amount of rinse water and fewer rinses, the rinse results are probably less than good; both suppliers and testing personnel have received complaints from customers about poor rinsing.

Energy labelling does not really extend to the effectiveness of rinsing, since there is no standardized method to measure this. The current process of standardization of the energy labelling for washing machines, how- 
ever, draws from a rinse test standard first introduced in the context of a joint Nordic development process. Nordic cooperation can therefore help to ensure that the effectiveness of rinse functions will be included in the next revision of the energy-labelling scheme.

Clothes and textiles, dirt, detergents and laundry habits have changed, which means that the ways in which washing machines are used have also changed. Clothes are washed more often and at lower temperatures than before, and handwash and wool cycles are used more commonly than before. As the laundry is seldom particularly dirty, it requires less mechanical force.

Energy labelling for washing machines does not correspond to actual use. Testing for energy labelling for washing machines is based on a $60^{\circ} \mathrm{C}$ cotton cycle only. While washing machines are always loaded with a full load when testing, most people do not put a full load in their machines. While the most common load in the Nordic countries is a little more than 3 kilogrammes per machine, the interviewees pointed out that there were now new machines that hold 7-8 kilogrammes of laundry, which meant that energy and water consumption per kilogramme was lower.

The tests covered a total of 144 appliances (between 12 and 30 per year). The load capacities of washing machines have increased. Before the energy-labelling scheme, the load ratio of a washing machine was $1: 13$, i.e. the internal volume of the drum was 13 litres per kilogramme of laundry. For an average-sized washing machine, the load capacity was thus 3 kilogrammes. Since 1996, the load ratio indicated for washing machines has been $1: 10$ or even 1:8. The average load capacity of washing machines tested in 1996 was 4.3 kilogrammes. In 2000-2005, the average load capacity for washing machines tested in the Nordic countries was 4.45-5.5 kilogrammes (Appendix 1, Table 20).

In the past ten years, the test cycle $\left(60^{\circ} \mathrm{C}\right.$ cotton) has lengthened by 25 minutes from 110 minutes to 135 minutes. Average energy and water consumption has decreased. The average electricity consumption of washing machines tested in 1996 was about $0.245 \mathrm{kWh}$ per kilogramme during a $60^{\circ} \mathrm{C}$ cotton cycle. The average electricity consumption of washing machines tested in 2000 for the same cycle was about $0.23 \mathrm{kWh}$ per kilogramme; in 2005, the average electricity consumption for the cycle was $0.20 \mathrm{kWh}$ per kilogramme. Between 2000 and 2005, average water consumption has has decreased from 16 litres per kilogramme of laundry to 10.3 litres (Figures 8 \& 9; Appendix 1, Tables 23-27).

The interviewees also pointed out that because the energy-labelled cycles took a long time to complete and water consumption was low, many machines offered short cycles and extra rinses. If laundry is always washed at $30^{\circ} \mathrm{C}$ or $40^{\circ} \mathrm{C}$ temperatures only and rinsed poorly, there will be a risk of a bad smell and mildew inside the machine. 


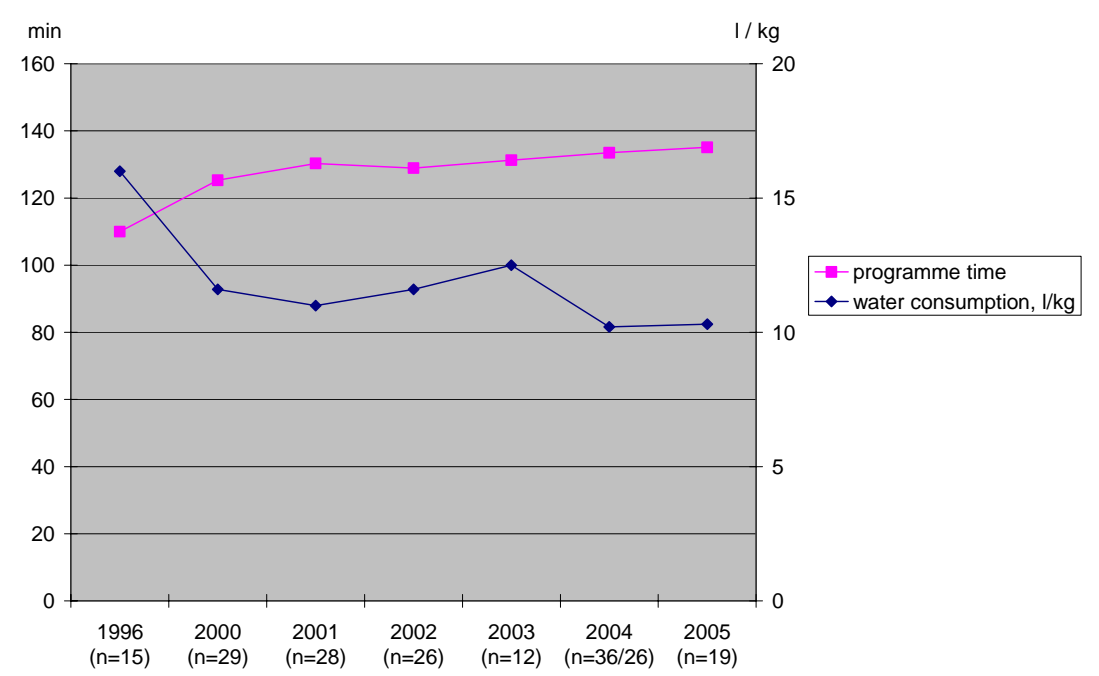

Figure 8 Lengths of cycles and consumption of water for washing machines tested in the Nordic countries in 2000-2005.

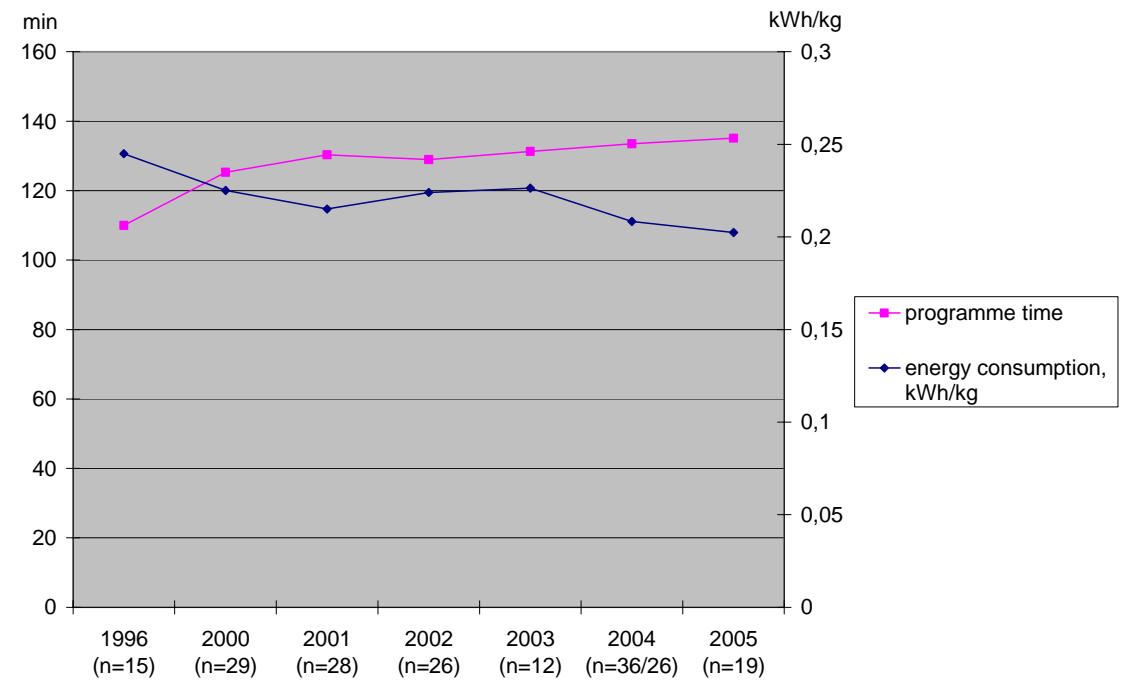

Figure 9. Lengths of cycles and consumption of energy for washing machines tested in the Nordic countries in 2000-2005

Washing machines have become more and more energy-efficient. In 1996, about half of the washing machines tested were rated $\mathrm{C}$ to $\mathrm{E}$ for energy efficiency. In 2005, only one machine fell into energy efficiency class $\mathrm{C}$, while more than $60 \%$ of the machines were rated A (Figure 10). A similar, though somewhat less conspicuous trend can be seen in the ratings for washing and spin-drying performance (Appendix 1, Figures 24 \& 25). 


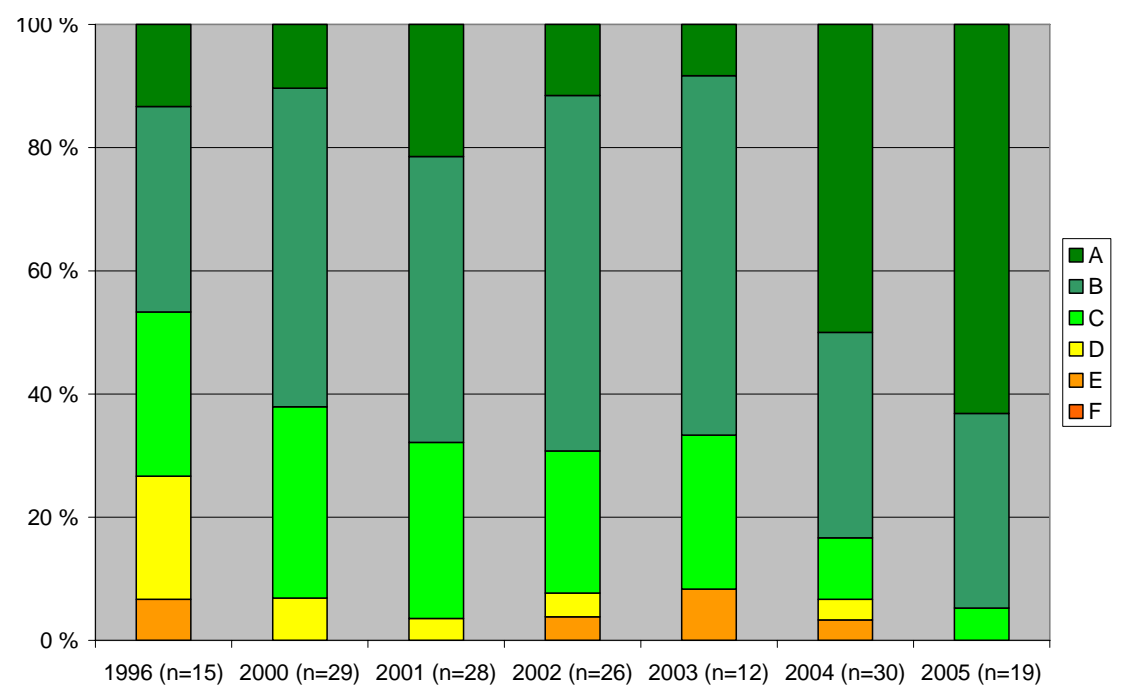

Figure10. Distribution of washing machines tested in the Nordic countries in 2000-2005 into energy efficiency classes.

Comments from testing personnel and suppliers:

"The biggest problem with washing machines and dishwashers is the long cycles. People have actually phoned the helpline because they think that there's something wrong with a machine that takes three hours to complete a cycle.”

"The best result from energy labelling is actually the improvement of the spin function. The lower the initial moisture of clean laundry, the less energy the tumble dryer will consume. Selecting a high spin speed therefore means lower energy consumption for the tumble dryer.”

"Consumers think that if they buy a washing machine with a good energy rating for its washing performance it will also rinse well, which in fact it won't."

\subsubsection{Tumble dryers}

The energy-labelling scheme has led to the development of products with lower energy consumption. Consumers can now choose from several low-energy tumble dryers, and heat pump technology for tumble dryers has also advanced significantly. Under the energy-labelling scheme, tumble dryers are tested for three programmes: basic, iron dry and cupboard dry. The initial moisture level of the textiles is now $60 \%$ instead of $70 \%$.

The selection of options, cycles and functions for tumble dryers has increased in recent years. Many tumble dryers are now equipped with special baskets for wool or shoes, for example. There are anti-crease and airing cycles and cycles for specific types of textiles.

\section{Slow improvement in the energy efficiency of tumble dryers}

A total of 62 tumble dryers (2 to 10 appliances per year) have been tested so far. The load capacities of tumble dryers have increased in line with 
those of washing machines. The average load capacity of tumble dryers tested in 1997-2005 was 4.7-5.5 kilogrammes (Appendix 1, Table 31). The average electricity consumption per kilogramme of laundry in tumble dryers has decreased slowly. In 1997, electricity consumption was 0.79 kWh per kilogramme; in 2005, it was $0.77 \mathrm{kWh}$ per kilogramme (Appendix 1, Table 133). Except for heat-pump tumble dryers, most of the tumble dryers tested fell within energy efficiency classes C to E (Figure 11).

Comments from testing personnel and suppliers:

"Tumble dryers achieve the desired degree of dryness better than before, but energy labelling has resulted in somewhat longer cycles.”

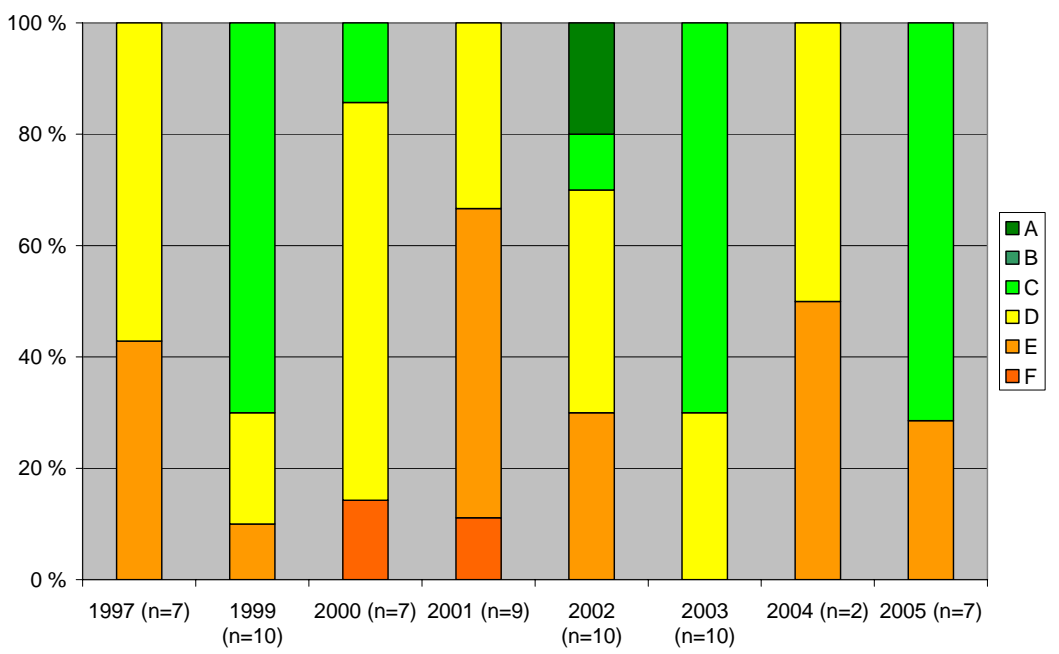

Figure 11 Distribution of tumble dryers tested in the Nordic countries in 1997-2005 into energy efficiency classes.

\subsubsection{Ovens}

Ovens are tested for energy labelling according to a standardized brick test, where a porous brick represents food (a joint of meat). The brick is placed inside the oven and the time it takes for the temperature of the brick to rise from $5^{\circ} \mathrm{C}$ to $60^{\circ} \mathrm{C}$ is measured. Before the test, the brick has been cooled down to $5^{\circ} \mathrm{C}$ and immersed in water to ensure its humidity during the test.

Because the standard for energy labelling for ovens was developed fairly recently, the energy consumption of ovens has not yet changed in any significant way. Manufacturers, are, however, paying more attention to lower energy consumption than before. More and more households are now buying A-rated ovens, which are increasingly available to buy. Nearly all ovens are now rated A or B for energy efficiency. 
According to the interviewees, an even heating performance was something that should be indicated on the energy label. Saving energy was not the main criterion for a typical household's choice of oven. Good heating properties - i.e. an even heating distribution - was considered the most important criterion.

The current standardization work carried out by the IEC's Technical Committee/Sub-Committee $59 \mathrm{~K}$ includes the development of a test method for the heating performance of ovens. This work is based on a Nordic cooperation project on the same topic.

It was also pointed out that the energy consumption of any oven depended a great deal on what sort of cooking the oven was used for. Because the user's cookery skills have a considerable bearing on how to save energy in the kitchen, ovens may not be a practical subject for energy labelling.

Most ovens tested are rated class $B$.

A total of 45 ovens (11 to 22 per year) have been tested so far. All tested ovens were medium-sized (Appendix 1, Table 35). Most ovens tested are rated class B for their energy efficiency. Because the energy labelling for ovens has been in place for a relatively short time, the test results do not show any significant trends (Figure 12).

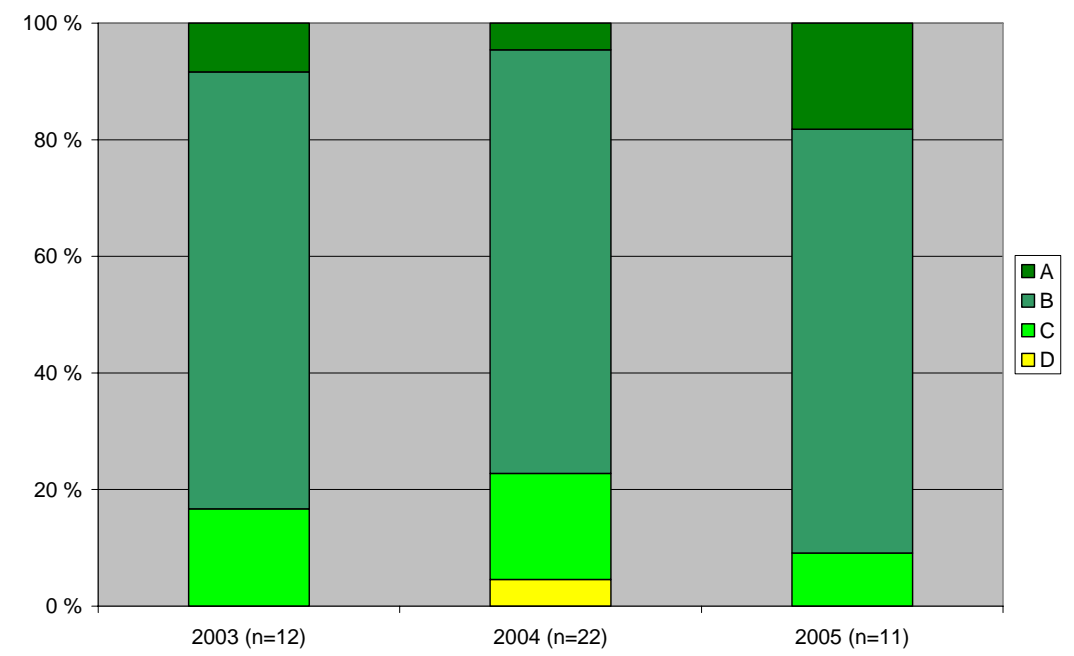

Figure 12 Distribution of ovens tested in the Nordic countries in 2003-2005 into energy efficiency classes.

\subsection{Can household appliances become more energy efficient?}

All interviewees agreed that energy labelling had led to the development of more energy-efficient household appliances. Consumer knowledge and awareness of the importance of energy issues and energy consumption 
had also increased, which meant that there was more interest in saving energy in households.

The latest A++-rated fridges and freezers are almost as energy efficient as they could possibly be. The greatest improvements have been made in the compressors and the insulation. If all cold appliances had electronic/digital temperature controls, it would be easier for users to set the right temperatures and thus increase the energy efficiency of the appliances.

With regard to washing machines, the interviewees doubted whether any further major improvements in the energy efficiency of the machines could be expected; improvement of the rinse function, however, was considered feasible. The interviewees did not think that further improvements in the energy efficiency of dishwashers nor in reductions in their water consumption were likely. However, the interviewees felt that new technologies such as new rinsing or jet systems, ultrasound or nanotechnology were quite possible.

\section{Comments from testing personnel and suppliers:}

"It is technically quite possible to develop household appliances that are more energy-efficient, but these would be too expensive for consumers."

"Thicker insulation in the walls and more efficient compressors could further reduce the energy consumption of cold appliances."

"Laundry could perhaps be cleaned with the help of ultrasound instead of water."

\subsection{The future of energy labelling}

Most of the persons interviewed had positive views on energy labelling. In their opinion, energy labelling provided important and objective information for consumers, who also often chose their appliances on the basis of the energy labels. Under the current energy-labelling scheme, however, manufacturers tend to focus on improving energy efficiency alone, setting aside other areas that may also need to be developed further. It was also pointed out by the interviewees that more attention should be paid to the differences in the ways people used their household appliances and the properties that the users considered important. While energy efficiency and good functionality should go hand in hand, the former should not impair the latter. 
Comments from testing personnel and suppliers:

"The energy-labelling scheme did have an impact on product development at the beginning, but it's becoming obsolete. We should find some other scheme to ensure that new products will be more environmentally friendly.”

"The energy-labelling scheme will extend to other product groups in the future."

"Energy labelling allows consumers to have an overview of the most energy-efficient appliances.”

"There will always be a need for some sort of a scheme. Energy labelling is here to stay but there could be a closer relationship with retailers."

"Energy labelling is a tool for retailers of household appliances."

"Energy labelling focuses far too much on energy consumption. In the case of washing machines, for example, energy consumption, washing and rinsing performance should all fall under the same rating. In that way, only energy-efficient machines with good washing and rinsing performance could be A-rated."

"Households won't buy them unless they are A-rated. It's impossible to sell products that haven't been awarded an energy label."

\subsection{Standardized test methods}

The information on energy labels is checked with tests based on European and international standards, which are often the results of several years of cooperation in the field of standardization.

Because the same methods for energy labelling checks are now widely used across Europe, the results of the tests are comparable between different testing bodies, which is a positive change from the days when each body applied its own test methods.

The interviewees believed that the testing methods will be developed and streamlined further in the future, ensuring comparability of the results. However, there may be a risk that only a handful of laboratories will have the resources required for such tests. Because large laboratories are taking over from smaller ones and carrying out tests for all parts of Europe. The suppliers interviewed suggested that the trend in testing methods was not necessarily the most favourable for consumers. Consumers are offered products with far too detailed specifications for normal household use. The testing methods for dishwashers were considered too strict and inconsistent with actual normal use by consumers. The dishes are usually much less dirty than presumed in the standard test.

Washing machines with a washing performance rated lower than $\mathrm{A}$ simply will not sell, even if they will mean lower energy consumption. On the other hand, suppliers also said that the requirements for energy labels were too low and needed to be tightened. 
It was also questioned whether the testing methods applied to energy labelling checks on washing machines reflected actual use. In some interviewees' opinion, the test should cover several cycles, e.g. the $40^{\circ} \mathrm{C}$ cotton cycle and the easy-care cycle.

The detergent used in the tests is not used for normal laundry, for which there are several different detergents available on the market. The laundry used in the tests is dirtier than normal laundry in households, which tends to be washed more often and is still fairly clean before washing.

The tests for tumble dryers use 'cotton cupboard-dry' as the default cycle, but the test load is too large and the initial moisture of the clean laundry too high to correspond to actual conditions in households.

In tests conducted on cold appliances, the internal volumes of the appliances are measured without the baskets, which gives exaggerated results for the freezing capacity. Upright models are always measured for their fullest loads, but are often much less full in actual use. The test results are also distorted by the various temperature zones and the no-frost function. The testpersonal interviewed suggested that the testing periods should be longer.

Some of the interviewees mentioned that some manufacturers abuse the tolerance margins allowed by the standard by stating larger freezing capacities and lower consumption of energy than the appliances actually have. 


\section{Experiences of households}

\subsection{Background information}

A total of 684 people participated in the survey, with most of the respondents from Finland (38.5\%) and the rest from Sweden (34\%) and Norway (27\%). Of the respondents, $48 \%$ were men and 52\% were women. Most respondents were aged 30-59 (73\%), and 38\% of their households consisted of two people. One-person households accounted for $18 \%$ of the respondents, as did three-person households.

Of the household appliances studied, washing machines had been bought the most since the introduction of energy labelling. As a singular household appliance combined washer-dryers had been bought the least, but as a product group, ovens had been bought the least (electric cooker and a built-in oven) in the last 3 years in the studied countries.

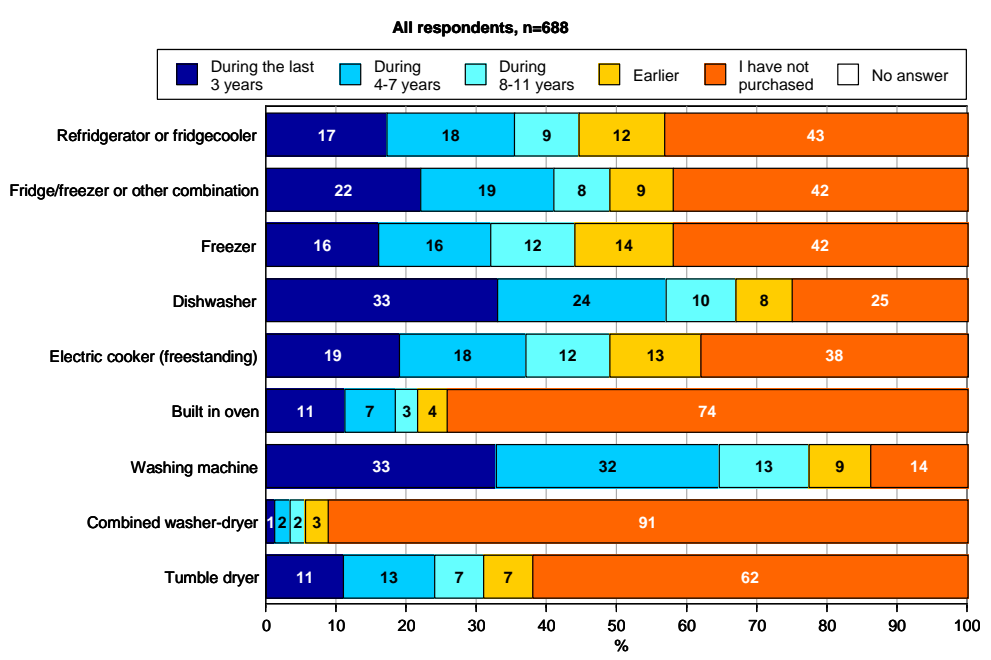

Figure 13 Time of purchase.

\subsection{Cold Appliances}

Energy labelling was introduced for cold appliances in 1995. Respondents were only questioned about cold appliances if they had bought a cold appliance in the last 11 years (Table 3). 
Table 3 The purchase of cold appliances.

\begin{tabular}{llll}
\hline & Refrigerators/fridge coolers & Fridge/freezer or other combination & Freezer \\
\hline Finland & $36 \%$ of participants & $43 \%$ of participants & $48 \%$ of participants \\
Sweden & $38 \%$ of participants & $39 \%$ of participants & $38 \%$ of participants \\
Norway & $59 \%$ of participants & $60 \%$ of participants & $45 \%$ of participants \\
\hline
\end{tabular}

\section{Households do not adjust the temperature of their refrigerator}

The respondents were asked some questions about their usage of cold appliances and about the appliances themselves. In all the countries surveyed the most usual temperature of the refrigerator is $4-6^{\circ} \mathrm{C}$ and the majority of respondents do not adjust the setting.

All in all, the majority of the participants at least somewhat agreed that their freezer is usually full. Over $40 \%$ of participants also at least somewhat agreed that their refrigerator is usually full.

A fifth of the participants clean their refrigerator regularly. A fifth or more of the respondents also defrost their freezer regularly.

The biggest difference between the studied countries in the use of cold appliances concerned the statement "I only use the freezer to store frozenfood products". Sixty per cent of Swedes thought this described their freezer use very well, while only $4 \%$ of Finns and $6 \%$ of the Norwegian thought so.

Correspondingly, there was a difference in the statement "I conserve by freezing", where more than a quarter of the Swedish participants strongly disagreed with the statement. In all countries, however, more than a third do conserve by freezing.

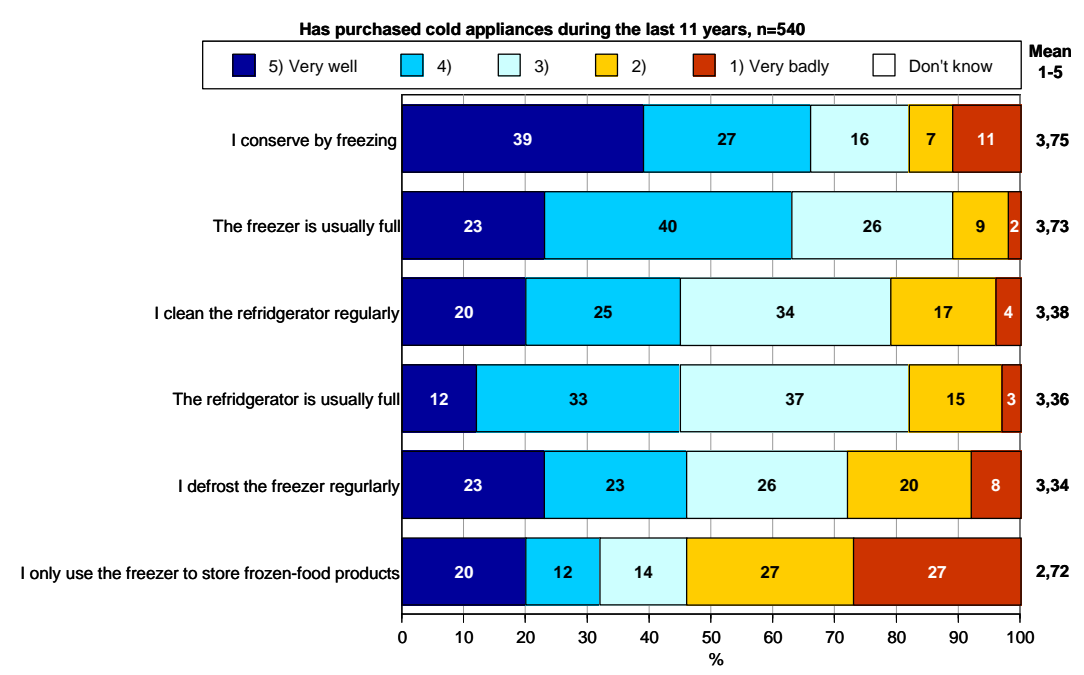

Figure 14 Statements on the use of Cold Appliances.

Households were unaware if the capacity of cold appliances had changed The Swedes more often agreed with the statement (34\% of participants)"The usable space of the cold appliance is smaller than before" than 
the Finns or the Norwegians. Quite a number of the participants did not know whether or not the usable space had changed.

The respondents mainly disagreed with the statement "The temperatures do not stay sufficiently low". Roughly two-thirds agreed with the statement "Foodstuffs freeze quickly in the freezer". The participants mostly disagreed with the statement "The noise of the appliance is disturbing”.

The Finns adopted quite a neutral stance on the statement "Cold appliances use a lot of electricity", whilst the Swedes and Norwegians more often stated "don't know". Finland was also the country with the most people who agreed with the statement, whilst the Norwegians agreed with it the least.

Lastly, the respondents were asked to assess how satisfied they were in general with their cold appliances. All in all the participants were quite satisfied (more than 90\%) with their cold appliances.

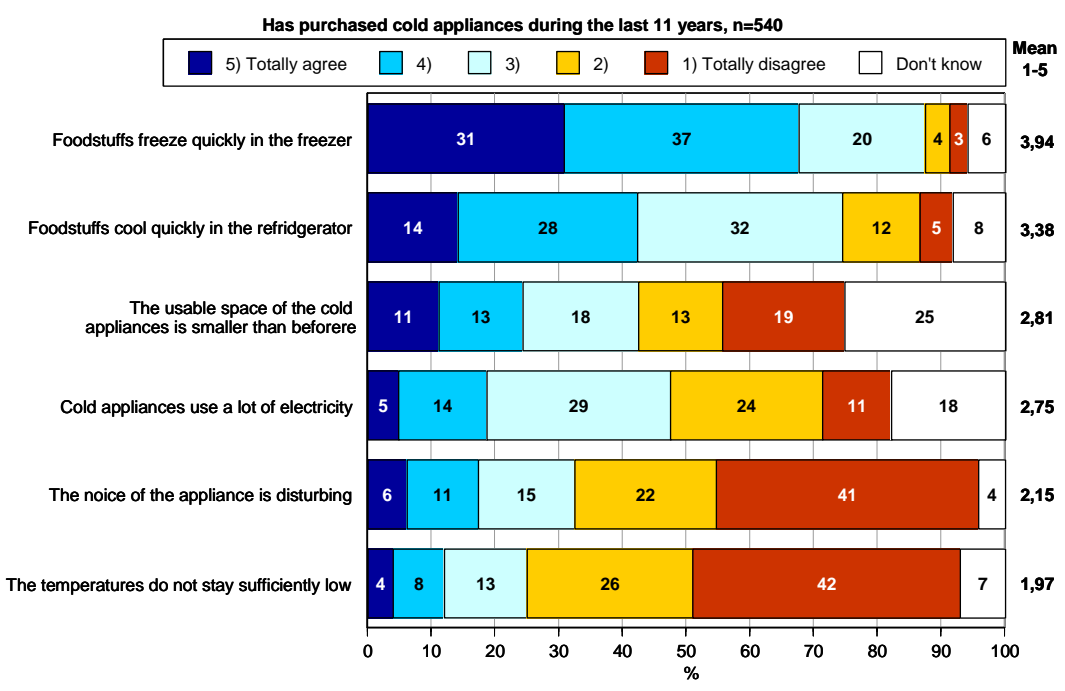

Figure 15. Statements on cold appliances.

Households that were not satisfied with their appliances were given an opportonity to provide reasons for their dissatisfation. The most common reasons, why some respondents were not satisfied were:

- fridges or/and freezers are noisy

- too little space inside the cold appliances

- too high or/and uneven temperature 


\subsection{Dishwashers}

Energy labelling was introduced for dishwashers in 1999. The questions about dishwashers were asked if the appliance was bought during the last 7 years.

- Finland $52 \%$ of participants

- Sweden $57 \%$ of participants

- Norway $62 \%$ of participants

\section{Households generally wash full loads}

In all the countries the dishwasher was usually connected to the coldwater source. About one-sixth of respondents did not know whether the dishwasher was connected to a hot- or a cold-water source.

About $90 \%$ of respondents use the dishwasher more than once a week. Almost all of the respondents agreed with the statement "I generally wash full loads". The respondents used quite high washing temperatures rather than short cycles and low temperatures. More than $60 \%$ of the respondents agreed with the statement "I rinse the dishes before I put them in the dishwasher".

The participants were also asked about the most used detergent type. There was a big difference between the studied countries regarding the statement "I use dishwasher detergents with environmental labels". The Norwegians generally agreed with the statement the most (71\% at least somewhat agree), whilst the Finns agreed with it the least (41\%). Also, regarding the statement "I use a rinsing agent", the Norwegians agreed with the statement the most (60\%), and the Finns the least (37\%).

Most participants disagreed with the statement "I clean the drainage filters of the dishwasher after approximately every second use".

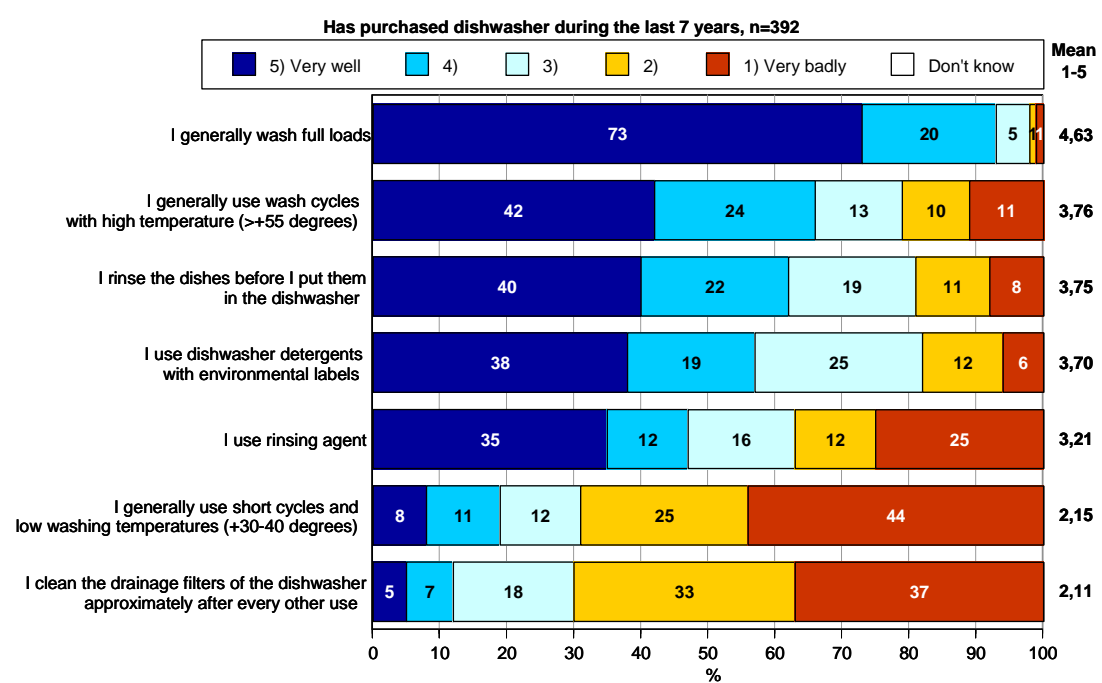

Figure 16. Statements on the use of dishwashers. 


\section{The dishwasher cycle takes too long}

The Finns did not agree quite as much with the statement "The dishes clean well in the dishwasher" as the Norwegians and Swedes, although even in Finland $75 \%$ of respondents did at least somewhat agree with this. In all the countries more than $70 \%$ of the respondents agreed with the statement "The glasses are gleaming after a dishwasher wash". Between the studied countries, the opinions were quite similar regarding the statement "The dishes get scratched quickly in the dishwasher". About a quarter agreed with this, and slightly less than a half of the participants disagreed with it.

About $70 \%$ of the respondents agreed with the statement "Placing dishes in the racks is easy". About half of the respondents agreed with the statement "The dishwasher is quiet". Not many though disagreed with this, as a substantial portion maintained a neutral viewpoint towards the statement. About half of the respondents agreed with the statement "The dishwasher cycle takes too long”.

The majority disagreed with "The dishes do not rinse well in the dishwasher". A large number of respondents totally disagreed with the statement "The dishwasher smells bad and musty". All in all, the participants in all of the countries were quite satisfied with their dishwashers.

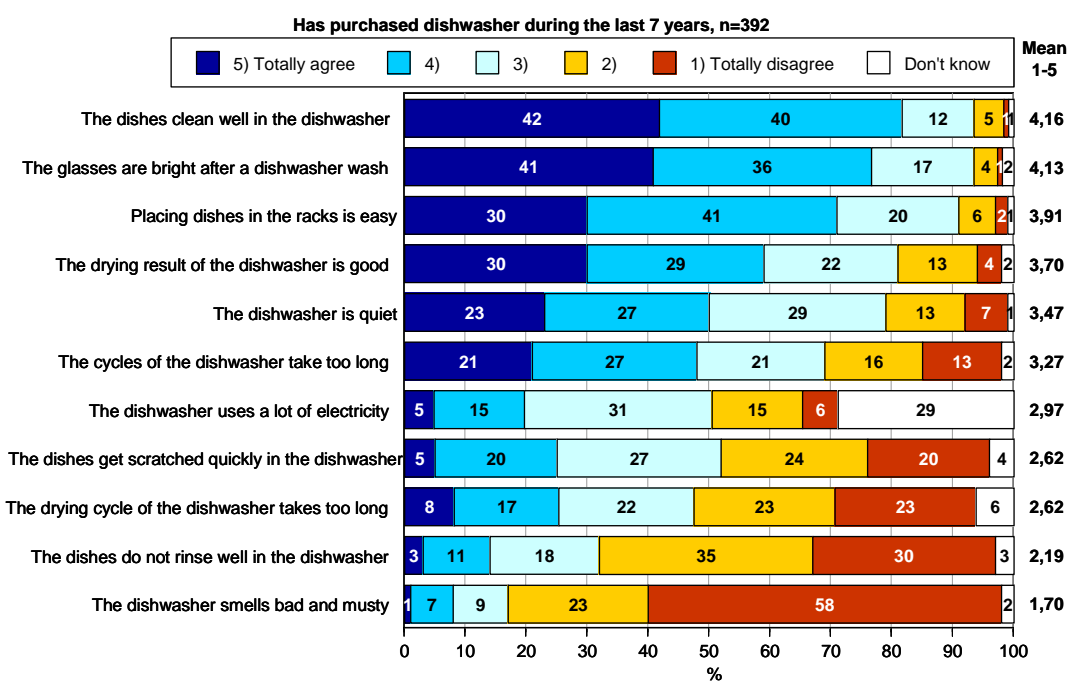

Figure 17 Statements on dishwashers. 
Households that were not satisfied with their appliances were given opportunity to provide reasons for their dissatisfaction. The most common reasons for dissatisfaction with dishwashers were:

- it takes too long

- washing result is poor

- makes too much noise

\subsection{Ovens (Free-standing electric cookers and built-in ovens)}

Energy labelling was only introduced for electric cookers and ovens in 2003. The questions about ovens were asked if the appliance had been bought in the last 3 years.

\section{Free-standing electric cookers}

- Finland $14 \%$ of participants

- Sweden $19 \%$ of participants

- Norway $23 \%$ of participants

\section{Built-in ovens}

- Finland 5\% of participants

- Sweden $12 \%$ of participants

- Norway $16 \%$ of participants

Households don't know if the oven uses a lot of electricity

Seventy per cent or more of the participants agreed with the statement "The oven bakes evenly". Also, there was general agreement with the statement "The oven heats quickly". The majority of participants disagreed with the statement "Baking takes longer than before". Also, the vast majority disagreed with the statement "The temperatures of the front face of the oven are too high".

The Swedes and Norwegians in particular often answered "don't know" to the statement "The oven uses a lot of electricity". The Finns were the most eager to agree with this (32\% agreed at least somewhat).

The largest disagreement with a statement could be seen with "The noise of the oven is disturbing". Here more than $80 \%$ of the participants disagreed with the statement.

The purchasers of ovens were generally quite satisfied with their appliances. Close to half of the participants were very satisfied with their oven. 


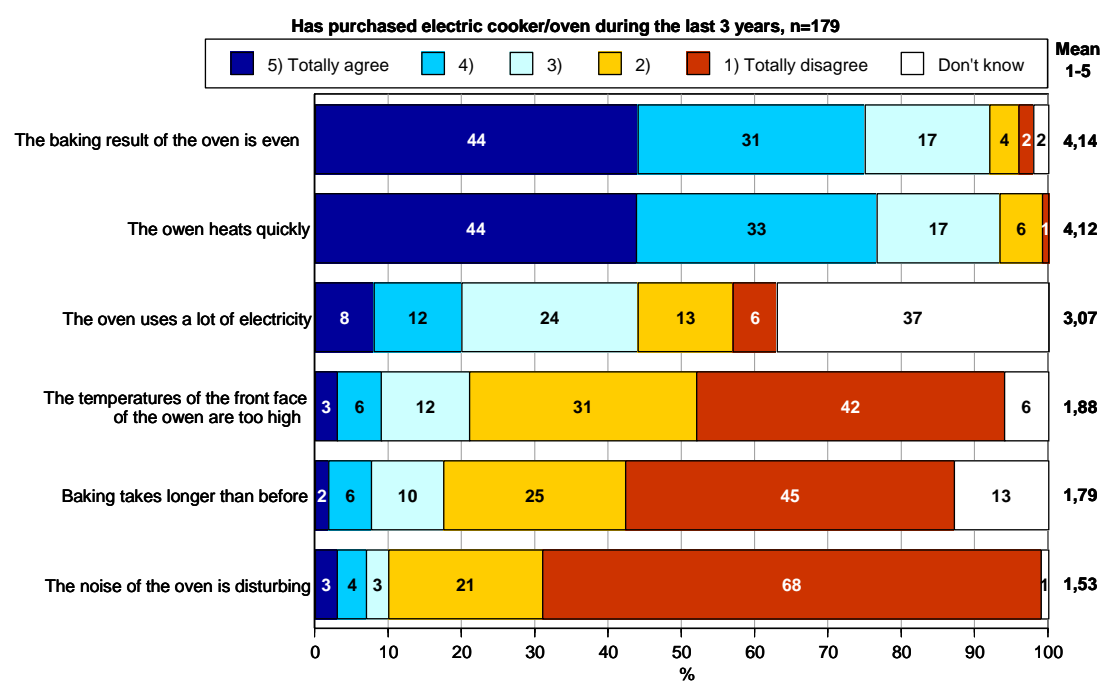

Figure 18. Statements on the use of ovens.

Households that were not satisfied with their appliances were given an oppornity to provide reasons for their dissatisfaction The most common reasons why some were not satisfied with their ovens were:

- noise

- uneven baking result

- takes too long to heat up

\subsection{Washing machines (Washing machines and combined washer-dryers)}

Energy labelling was introduced for washing machines and combined washer-dryers in 1996. The questions about these appliances were asked if the appliance was bought in the last 11 years.

\section{Washing machines}

- Finland $82 \%$ of participants

- Sweden $64 \%$ of participants

- Norway $85 \%$ of participants

Combined washer-dryers

- Finland 3\% of participants

- Sweden $4 \%$ of participants

- Norway $8 \%$ of participants 
The washing water temperature that is most often used is $+40^{\circ} \mathrm{C}$

The most common usage frequency was $2-5$ loads a week. In Finland the washing machine was not used quite as often as in Sweden or Norway.

The Finns more often agreed (79\% at least somewhat agree) with the statement "The washing water temperature I most often use is $+40{ }^{\circ} \mathrm{C}$ " than the Swedes (66\%) or the Norwegians (64\%). The Swedes agreed the most (65\% agreed at least somewhat) with the statement "I never use the white washing programmes $\left(90-95^{\circ} \mathrm{C}\right)$.

The participants divided quite evenly between agreeing and not agreeing with the statement "I usually wash my laundry with a short or quick cycle".

About $80 \%$ of participants disagreed with the statement "I always wash half-full loads". Also, the statement "I always or almost always choose an extra rinse or rinses" was widely disagreed with. More than $80 \%$ of the participants also disagreed with the statement "I always or almost always choose extra water for the wash and/or rinse cycle".

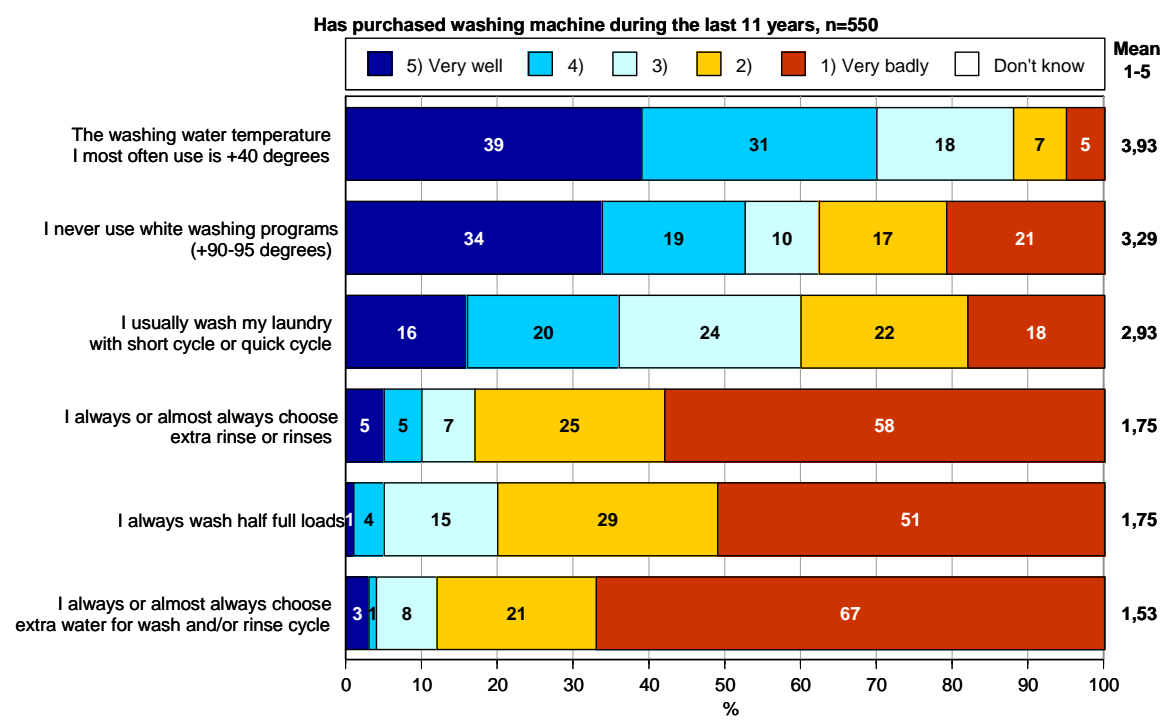

Figure 19 Statements on the use of washing machines.

The washing cycles of the washing machine take too long

The participants were asked some statements about the washing machines themselves. The Finns agreed the most (48\% of participants at least somewhat agree) and the Norwegians the least (34\%) with the statement "The washing cycles of the washing machine take too long".

More than $80 \%$ of participants in all the studied countries agreed with the statement "The laundry comes out clean". Almost 70\% of the Swedes disagreed with the statement "Light-coloured textiles turn greyish". The Finns disagreed with the statement the least (48\% of participants at least somewhat disagreed). Also, the Finns disagreed the least (54\%) with the 
statement "Dark textiles seem dusty (detergent residues), while $66 \%$ of the Swedes and Norwegians disagreed with the statement.

The participants more often disagreed than agreed with the statement "The textiles get linty". The statement "The textiles smell bad after washing" was disagreed with by about $90 \%$ of participants. Also, the statement "The laundry does not rinse well in the washing machine" was widely disagreed with amongst the participants. More than $70 \%$ of the participants disagreed with the statement "The washing machine smells bad and musty".

Many participants, especially in Sweden and Norway, answered "don't know" to the statement "The washing machine uses a lot of electricity". In Finland and Sweden more people disagreed than agreed with the statement, but in Norway the opinions divided quite evenly.

Many participants answered "don't know" to the statement "The washing machine uses too little water". Only about $10 \%$ or less agreed with the statement in each country.

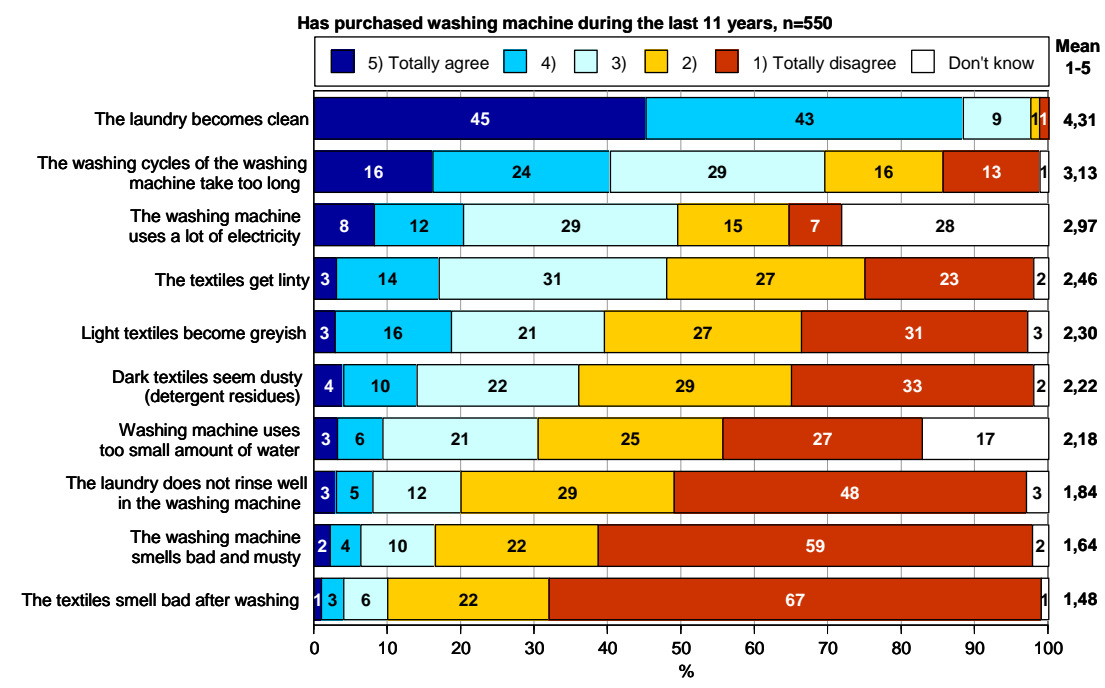

Figure 20 Statements on washing machines.

Lastly, the participants were asked about the most often used detergent type, and about their general satisfaction with their washing machine. In all of the countries, but especially in Norway, the traditional powdered detergent was used most often. In Finland concentrated detergent powder was used more than in the other countries. In Norway liquid detergents were used less than in Finland or Sweden, but detergent tablets were used more than in the other countries.

Almost all of the participants in all the studied countries were at least fairly satisfied with their washing machine. The most unsatisfied participants can be found in Sweden. 
Households that were not satisfied with their appliances were given an oppornity to provide reasons for their dissatisfation. The most common reasons for not being satisfied with the washing machine were:

- the clothes do not come out clean

- it does not rinse properly

\subsection{Tumble dryers (Combined washer-dryers and tumble dryers)}

Energy labelling was introduced for combined washer-dryers and tumble dryers in 1996. The tumble dryers had been bought as follows in the last 11 years:

\section{Combined washer-dryers}

- Finland 3\% of participants

- Sweden $4 \%$ of participants

- Norway $8 \%$ of participants

\section{Tumble dryers}

- Finland $19 \%$ of participants

- Sweden $27 \%$ of participants

- Norway $44 \%$ of participants

The tumble dryer is used 2-5 times per week

The majority of participants most often use the tumble dryer for 2-5 loads per week or more. The statement "I dry all textiles in the tumble dryer" was agreed with considerably more in Finland than in the other countries. Most people in Sweden and Norway disagreed with the statement.

More than half of the participants disagreed with the statement "I always dry half-full loads". Also the statement "I use the tumble dryer to air and unwrinkle textiles" was widely disagreed with.

The statement "I often use a timer" was clearly more often disagreed than agreed with in all the studied countries. 


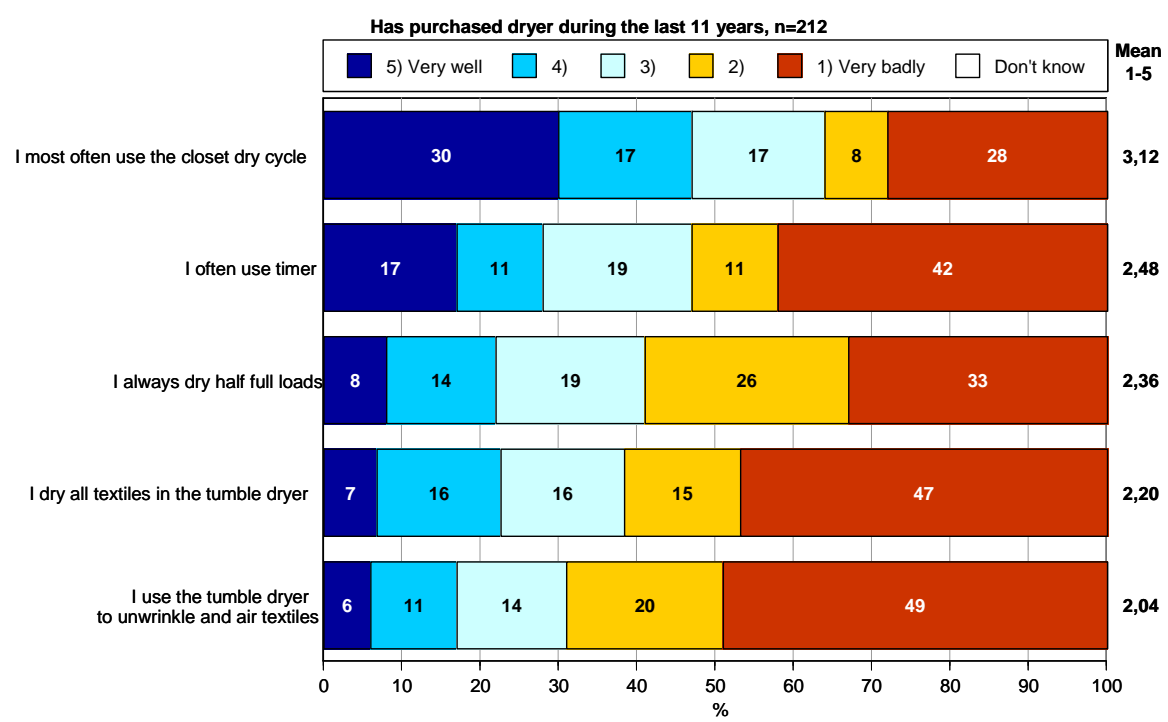

Figure 21 Statements on the use of dryers.

The use of a tumble dryer reduces the need for after-treatment of textiles Most of the participants agreed that the laundry dries quickly in the tumble dryer. More than $60 \%$ of participants also agreed that the drying result of the tumble dryer was even. Even here, the Finns agreed with the statement the most, and the Norwegians the least.

Also, the statement "The use of tumble dryer reduces the need for after-treatment of textiles, e.g. ironing and mangling” was agreed with the most in Finland (71\% at least somewhat agreed) and the least in Norway (41\%).

Almost half of the Norwegians agreed with the statement "The textiles shrink in the tumble dryer", whilst only a third of the Finns agreed with it.

The differences between the countries were considerable regarding the statement "The textiles come out too wet from the tumble dryer", with the Finns disagreeing with the statement the most (78\%) and the Norwegians the least (54\%).

About half of the participants in all the studied countries agreed that the tumble dryer uses a lot of energy. Many participants also answered "don't know" to this statement.

More than $80 \%$ of participants in all the studied countries were satisfied with their tumble dryer. 


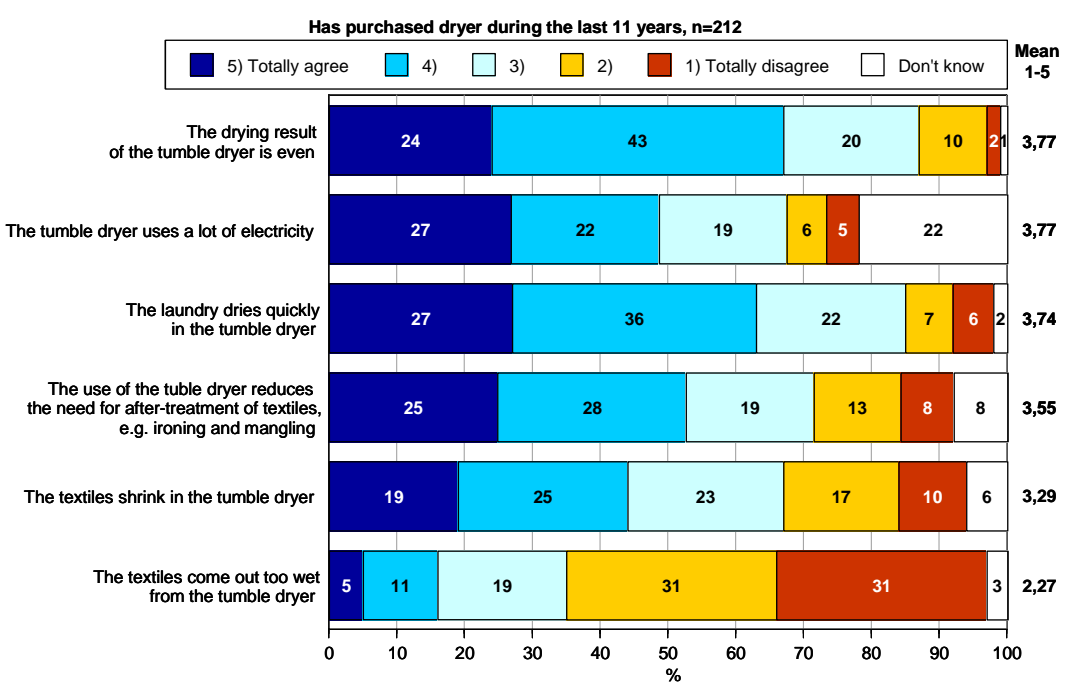

Figure 22 Statements on dryers.

Households that were not satisfied with their appliances were given an oppornity to provide reasons for their dissatisfation. The most common reasons why some were not satisfied with their tumble dryers were:

- it takes too long

- drying results are poor

\subsection{Energy labelling}

All the participants who had bought at least one of the studied household appliances since they have had the energy labelling, were asked for their opinion on some statements regarding their knowledge of the energy labelling when purchasing a household appliance.

About half of the participants agreed with the statement "I was already familiar with the energy labelling system before I purchased the appliance". Half or almost half of the participants agreed with "Saving energy was an important purchase criterion when acquiring a new household appliance".

The differences between the countries were noticeable regarding the statement". The information given by the energy label clearly facilitated the choice of the appliance". The Finns agreed with the statement the most (51\% at least somewhat agreed), and the Norwegians the least (34\%). 
In all the countries the participants agreed quite well with the statement "The energy label facilitated comparing appliances when purchasing the appliance" rather than disagreed with it.

In Finland and Sweden a bigger share of respondents agreed with the statement "I received adequate information on the energy labelling when purchasing the appliance" than disagreed with it. In Norway the share of those disagreeing was greater.

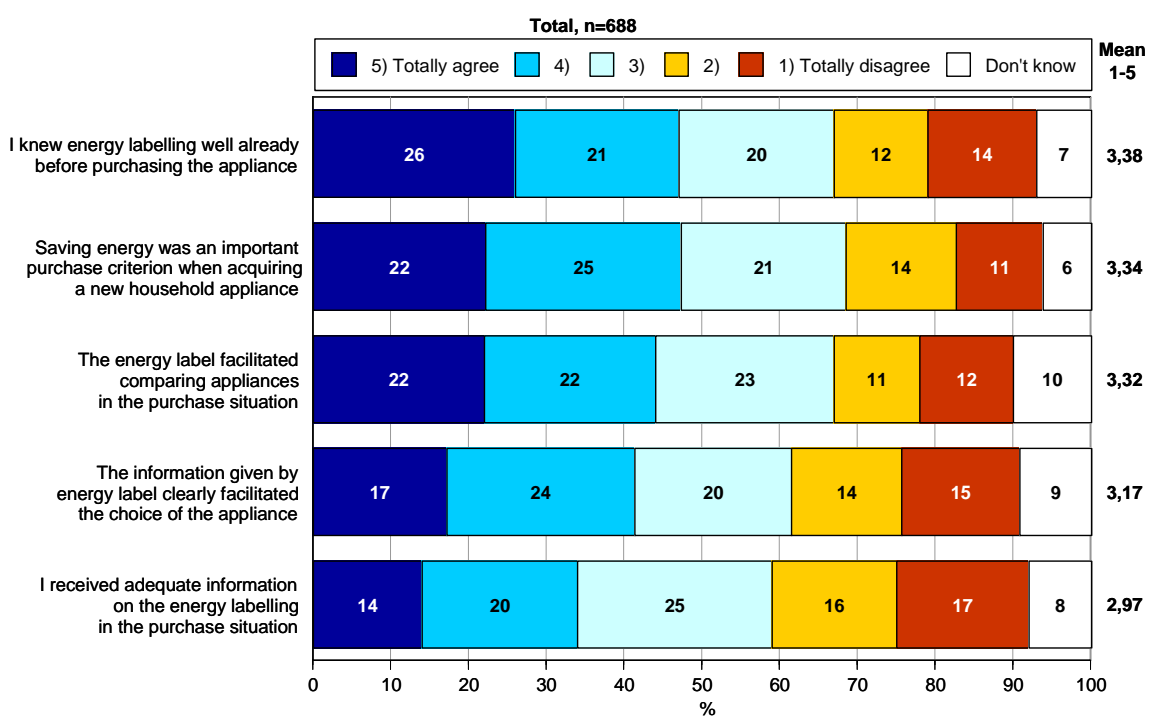

Figure 23 Statements on energy labelling when purchasing a household appliance.

\subsection{Owners are satisfied with their appliances}

Tests on household appliances have shown that energy labelling has in some cases altered the performance of household appliances in a way that is not necessarily favourable to the consumer. Washing cycles for dishwashers and washing machines have become longer and the load capacity of washing machines higher. The freezing capacity of freezers is lower than than in older models.

When asked about their actual use of their household appliances and about their opinions on them, households in Finland, Norway and Sweden proved on the whole very satisfied with their appliances. More than $90 \%$ of the households surveyed were satisfied with their appliances, with ovens rated highest on their list and tumble dryers lowest.

Half of the households surveyed were familiar with the energylabelling scheme and energy labels had a significant influence on their choices of appliance. However, opinions differed on the adequacy of the information provided on the energy label both before the purchase of the appliance and at the time of the purchase and on whether the information had influenced the choice of appliance or even made it easier. According 
to the results of the survey, most households did not know how much energy their appliances consumed.

The survey also showed that:

- Most households had not noticed that the capacity of cold appliances had become lower or that the freezing times took longer than before. Households considered that their fridges and freezers were full.

- Households fully loaded their dishwashers and rinsed the dishes before putting them into the dishwasher. The dishwashers were connected to cold-water lines.

- Households set dishwashers at higher temperatures. They were satisfied with the washing performance of their dishwashers. Nearly a half of the households felt that the dishwasher cycles were too long.

- Households washed their laundry at lower temperatures and were very satisfied with the results. Many felt that the cycles were too long.

- Only a few households reported any bad smell in their washing machines or dishwashers.

- Most households did not think that their washing machines rinsed poorly, nor was the extra rinse function used very often.

The most common complaint made by households that were unsatisfied with their appliances was the noise from the cold appliance, oven or dishwasher. 


\section{Conclusions}

The purpose of the project was to identify changes implemented in household appliances in the Nordic market since the introduction of the compulsory energy label and the effect of energy labelling on the use of the appliances by households. Another aim was to establish whether households could choose the most energy-efficient appliances on the basis of the label information and whether the energy-labelling scheme corresponds to the actual use of the appliances.

\subsection{Household appliances in the Nordic market has changed}

Both the testing personnel and the suppliers in the Nordic countries agree that energy labelling has influenced and steered the product development of household appliances. Household appliances consume considerably less energy and water than they did before the implementation of the energy-labelling scheme. In the case of dishwashers, the low energy consumption has been achieved through longer washing and drying cycles that can take up to three hours; longer cycles have reduced the energy consumption in washing machines, too. Today's washing machines and dishwashers have a higher load capacity, which is both an advantage and a disadvantage. Full loads save energy, but there often simply is not enough laundry for a full load.

Better insulation in fridges and freezers has resulted in reduced internal volume. The compressors, too, have been reduced in efficacy. Freezers have a lower freezing capacity than before. Energy consumption will be lower if a longer time is allowed for the freezing of foods, but this will impair the quality of the frozen foods. Manufacturers have also launched larger (free-standing) cold appliances onto the market.

The energy-labelling scheme has accelerated the trend towards larger appliances and the selection of smaller-sized appliances on the market is shrinking, despite the fact that the number of small households is increasing in the Nordic countries. The energy label requirements are easier to meet with larger appliances.

One of the advantages brought on by energy labelling is that the spin cycles of washing machines are very efficient, thus saving energy when the laundry is dried. Energy labelling involves strict requirements for the washing performance. If these requirements were made less stringent, the energy efficiency could be higher. 
Some of the interviewees among both the testing personnel and the suppliers suspected that energy labelling has in fact resulted in poorer rinsing in washing machines, which could be due to the low water consumption. Energy labelling does not really cover the effectiveness of rinsing, since there is no standardized method to measure this.

The heating performance of ovens cannot be properly tested under the energy-labelling scheme, either, nor are there any methods for measuring the evenness of the heating distribution.

\subsection{Energy label tests do not correspond to actual use}

According to the EU energy labelling rules, tests applied to the measurement of energy efficiency must reflect actual use of the appliances by consumers.

The test methods designed for dishwashers do not reflect actual use, as dishes in real households are less dirty than presumed in the test standard. Manufacturers can decide themselves on the design and temperatures of the cycles selected for energy labelling. The energy-labelled cycles and their names may vary from one model to another. To achieve the energy efficiency indicated on the energy label, users would have to know which particular cycle the energy label actually refers to.

Washing machines are often run at low temperatures and with less than full loads, while energy labels are granted on the basis of the washing machine's performance at the $60^{\circ} \mathrm{C}$ cycle. A more accurate basis for an energy label would be the average level of energy consumption based on half and full loads and different temperatures.

Some of today's washing machines take loads of up to 8 kilogrammes, according to the information supplied by the manufacturers. There are few households that can actually fill the machine with that much laundry, even if it means greater energy efficiency. Many households choose appliances that have too much capacity for the household's needs, which is why half loads in washing machines are very common in small households. The energy-labelling scheme should steer product development towards smaller-sized appliances aimed at the large number of small households today.

The detergents used in the energy efficiency tests of washing machines are not those normally used by households. The level of dirtiness presumed in the tests does not correspond to real life, either; in reality, clothes are washed fairly often and are not really dirty before washing.

The test loads for the 'cotton cupboard-dry' cycle in tumble dryers are too large and fail to correspond to actual loads. 


\subsection{Smart choices for households}

Making energy labelling compulsory has steered product development towards more efficient household appliances to such an extent that it is already hard to envisage any further improvements through existing technology. Because most appliances sold in shops are now rated A or B, even households that are not familiar with energy labelling will have energy-efficient appliances.

The energy-labelling scheme does not correspond to the actual use of the appliances by households. Households may well choose appliances that have received energy labels for efficiency, but the way that they use them may consume a lot of energy.

Energy labelling has made households more aware of energy consumption and more motivated to save energy. There may be additional ways in which households can use their appliances to save energy. According to the survey, many households do not adjust the internal temperatures of their cold appliances; also, dishes are often rinsed in running water before they are loaded into the dishwasher.

\subsection{Has energy labelling had any impact on how appliances are used by households?}

According to the survey, more than $90 \%$ of the households surveyed were satisfied with their appliances. Half of the households surveyed were familiar with the energy-labelling scheme and energy labels influenced their choices of appliances significantly. However, the survey did not reveal whether households used the appliances in a way that actually increased energy consumption, nor whether energy labelling had had any effect on the way the appliances were used.

Most households prefer short cycles for their laundry, and as a result the energy-labeling cycle is seldom used because it takes a long time. In many cases, the reasons for choosing shorter cycles and lower temperatures are shortage of time and the fact that the laundry is not very dirty. Low-temperature cycles are also selected because they are recommended in the care instruction labels on many garments. From the perspective of saving energy, washing the laundry at low temperatures is a positive thing; however, many textiles require a $60^{\circ} \mathrm{C}$ wash for a clean result. Today's washing machines also allow individual cycle combinations with extra rinses. 


\subsection{The Work still to be done}

Energy labelling has had an impact on the development of household appliances. Today's appliances are energy-efficient and users are satisfied with them; however, the test methods applied to energy labelling do not always correspond to the actual use of the household appliances. Although the current energy-labelling scheme focuses on saving energy, the appliances must also fulfil their functions properly. Energy labelling helps households to choose appliances that save energy, but more savings could still be made in the ways the appliances are actually used.

The work on improving the energy-labelling scheme and helping households save energy more efficiently should focus on:

- Studies on how consumers use their household appliances and how such ways affect energy consumption. These can be explored through interviews and by observing household habits related to using the appliances.

- Test methods applied to energy labelling. These methods should be developed further and modified to correspond to the actual use of the appliances by households. One of the requirements for granting an energy label should be to ensure that the appliances function properly in everyday life and are designed for all users.

- The information on the energy labels. To help households reduce their energy consumption, the energy labels must be more informative. Measures should be taken to create an energy-labelling scheme that will actually advise consumers on saving energy.

- The information provided by sales personnel. Sales personnel at retail shops must be trained to provide customers with information on how to save energy.

- Development of small, attractive household appliances. Households should have the opportunity to choose their appliances on the basis of their own needs and habits, which requires a wide enough selection of small appliances on the market. 


\section{References}

Arild, A., Brusdal, R., Halvorsen Gunnarsen, J. T., Tersptra, P. M. J, \& van Kessel, I. A. C. 2003. An Investigation of Domestic Laundry in Europe habits, hygiene and technical performance. Professional report No. 12003. SIFO. $130 \mathrm{p}$.

Elschenbroich, A. \& Gördeler, G. 2006. Promotion of sustainable washing and dishwashing in a nationwide action day in Germany.

http://mail.mtprog.com/Presentations/S ession_B/B4AElschenbroich.pdf

Forbruker-raporten 1/2001, 2/2001, 4/2001, 8/2002, 2/2003, 1/2004, 5/2004, 1/2005, 2/2005

Humala, I. (ed). 1999. Optimising energy efficiency conditions for household appliances. Final report. Save II Project. Työtehoseuran julkaisuja 368. 128 p.

Korhonen, A.2006. Kylmäsäilytyslaitteiden sähkönkulutus käyttöolosuhteissa. Työtehoseran raportteja ja oppaita 31. 18 s + liitteet. Saatavissa: http://www.tts.fi/tutkimus/julkaisut/fil es/tr31.pdf

Novem. 2001. Revision of energy labelling \& targets washing machines (clothes). Study for the DirectorateGeneral TREN of the Commission of the European Communities. Final report. $76 \mathrm{p}$.

Owen. J. 2004. Lower Temperatures and Smaller Loads. How a change in energy label data could help achieve a reduction in domestic energy use. Market Transformation programme.

Råd \& Resultater 4/1996.

Råd\&rön 5/1996, 2/2000, 9/2000, 10/2001, 9/2003, 1/2004, 1/2005, $3 / 2005$.

Statens energimyndighet. 2006. Grönare vitvaror. De första tio åren med energimärkning - butikskontroller och tester. $48 \mathrm{p}$.

Taenk 9/2000, 10/2000, 12/ 2001, 13/2001, 16/2001, 29/2002, 21/2002, 22/2002, 24/2002, 27/2002, 31/2003, 40/2003, 41/2004, 42/2004, 45/2004, 49/2004, 47/2005, 52/2005, 57/2005.

Terpstra, P. M. J. 2003. Energy labelling of Laundry Appliance; setting the future standards. Energy Efficiency in Domestic Appliances and Lighting. Proceedings of the $3^{\text {rd }}$ International Conference on Energy Efficiency in Domestic Appliances and Lighting. Part II. p. 717-724.

Työtehoseuran kotitaloustiedotteet, 2/1995 (502), 9/1995 (509), 7/1996 (517), 8/1996 (518), 9/1996 (519), 4/1999 (544), 9/1999 (549), 2/2000 (552), 4/2000 (554), 9/2000 (559), 1/2001 (561), 3/2001 (563), 1/2002 (571), 5/2002 (575), 7/2002 (577), 9/2002 (579), 2/2004 (592), 3/2004 (593), 5/2004 (595), 7/2004 (597), 1/2005 (601), 4/2005 (604). 



\section{Tiivistelmä}

Kotitalouskoneiden energiamerkintä on pakollinen ja yhtenäinen EUmaissa. Energiamerkinnän tarkoituksena on antaa kuluttajille tietoa kotitalouskoneiden energian kulutuksesta ja muista tärkeistä ominaisuuksista, niin että kotitaloudet voivat valita mahdollisimman energiatehokkaita koneita. Energiamerkittyjä kotitalouskoneita ovat kylmäsäilytyslaitteet, pyykin- ja astianpesukoneet, kuivaavat pesukoneet, kuivausrummut ja uunit.

Energiamerkinnän säännösten mukaan energiatehokkuusmittauksissa käytettyjen testausmenetelmien tulee vastata kotitalouksien normaalia tapaa käyttää koneita. Kotitalouskoneet ovat muuttuneet energianmerkinnän myötä eivätkä kaikki muutokset ole olleet hyviä kotitalouksien kannalta. Pyykin- ja astianpesukoneiden pesuohjelmat pidentyneet ja pyykinpesukoneiden täyttösuhteet ovat nousseet. Pakastimien pakastuskyky on heikentynyt.

Projektin tavoitteena oli selvittää, kuinka kotitalouskoneet Pohjoismaisilla markkinoilla ovat muuttuneet energiamerkinnän myötä ja onko se on vaikuttanut kotitalouksien käyttötapoihin. Lisäksi projektissa selvitettiin voiko kotitalous tehdä energiatehokkaan valinnan energiamerkin tietojen perusteella sekä vastaako energiamerkintä koti-talouskoneiden todellisia käyttötapoja.

Projektissa koottiin tuloksia Pohjoismaissa testatuista energiamerkityistä kotitalouskoneista sekä haasteltiin testaushenkilökuntaa ja kodinkoneiden markkinoijia energiamerkinnän vaikutuksista kotitalouskoneisiin.

Taloustutkimus Oy teki Internet-paneelitutkimuksen kotitalouksille Norjassa, Ruotsissa ja Suomessa. Kyselyn kohderyhmä oli 20-65 vuotiaat kuluttajat, jotka olivat ostaneet ainakin yhden energiamerkityn kotitalouskoneen. Kotitaloudet vastasivat kotitalouskoneiden käyttöä ja itse konetta koskeviin kysymyksiin ja väittämiin. Heiltä kysyttiin myös energiamerkinnästä.

Tutkimus osoitti, että energiamerkinnän noin 10-vuotisen historian aikana kotitalouskoneista on tullut yhä energiatehokkaampia. Kylmäsäilytyslaitteiden energiatehokkuus on parantunut eniten. Pyykin- ja astianpesukoneiden energiatehokkuus on myös parantunut, mutta osittain ajan kustannuksella. Kylmäsäilytyslaitteiden eristeet ovat entistä paksummat, joten käyttötilavuus on pienentynyt. Lisäksi pakastimen pakastuskyky on heikentynyt. Kuivausrumpujen energiatehokkuus on parantunut hitaasti, mutta uuden tekniikan myötä niiden energiakulutus voi laskea. Uunien energiamerkintä on ollut voimassa niin lyhyen aikaa, ettei energiamerkinnän vaikutuksista uunien energiankulutukseen voi vielä sanoa. Ener- 
giatehokkuusvaatimukset uuneille ovat alhaisilta, sillä alusta alkaen useimmat uunit ovat olleet energiatehokkuusluokkaa A tai B.

Sekä kotitalouskoneiden testaajat että markkinoijat olivat samaa mieltä, että energiamerkintä on vaikuttanut ja ohjannut kotitalous-koneiden tuotekehitystä. Energiamerkintä on johtanut yhä suurempiin koneisiin ja pienien kotitalouskoneiden valikoima on pieni siitä huolimatta, että kotitalouksien keskikoko Pohjoismaissa on pienentynyt. Isompien kotitalouskoneiden on helpompi saavuttaa hyvä energia-tehokkuusluokka.

Muutamat testaajat että markkinoijat epäilivät, että energiamerkinnän seurauksena pyykinpesukoneiden huuhtelutulos on heikentynyt alhaisen veden kulutuksen vuoksi. Huuhtelutulos ei sisälly energiamerkkiin, koska sen määrittämiseen ei ole olemassa standardoitua menetelmää. Samasta syystä paistontasaisuus ei sisälly uunin energiamerkkiin.

Kysely kotitalouksille osoitti, että yli 90 prosenttia kotitalouksista on tyytyväinen kotitalouskoneisiinsa. He olivat tyytyväisimpiä uuneihinsa ja vähiten tyytyväisiä kuivausrumpuihin. Useimmat kotitaloudet eivät ole huomanneet, että kylmäsäilytyslaitteiden käyttötilavuus on pienentynyt ja, että pakastuminen vie enemmän aikaa kuin aiemmin. Kotitalouksien mielestä jääkaappi ja pakastin ovat yleensä täysiä. He pesevät yleensä täysiä koneellisia astianpesukoneella ja huuhtelevat astiat ennen koneeseen laittamista. Astianpesukoneet ovat useimmiten liitetty kylmään veteen ja kotitaloudet käyttävät korkeita lämpötiloja. Kotitaloudet ovat tyytyväisiä astianpesukoneen pesu- ja huuhtelutuloksiin. Lähes puolet on kuitenkin sitä mieltä, että astianpesukone pesee liian kauan. He pesevät pyykin alhaisissa lämpötiloissa ja ovat erittäin tyytyväisiä pesutulokseen. Monen mielestä pesuohjelmat kestävät liian kauan. Enemmistön mielestä pyykinpesukoneen huuhtelutulos on hyvä ja lisähuuhteluita ei käytetä kovin paljon.

Energiamerkintä on vaikuttanut kotitalouskoneiden tuotekehitykseen. Koneet ovat energiatehokkaita ja kotitaloudet ovat tyytyväisiä niihin. Energiamerkinnän testausmenetelmät eivät kuitenkaan vastaa aina kotitalouksien tapaa käyttää koneita. Nykyisin energiamerkintä keskittyy energiansäästöön, mutta on myös tärkeää, että kotitalouskoneet toimivat. Energiamerkinnän ansiosta kotitaloudet saavat energiatehokkaita koneita, mutta kotitalouksien käyttötavoissa on yhä energiansäästömahdollisuuksia.

Tulevaisuudessa energiamerkintää on parannettava ja energiansäästöä kotitalouksissa on tehostettava seuraavasti:

- Tutkimusta kotitalouksien käyttötavoista ja käytön vaikutuksesta energiankulutukseen. Haastattelemalla kotitalouksia ja havainnoin-noimalla heidän toimintaansa kotona, jossa kotitalouskoneita käytetään.

- Energiamerkinnän testausmenetelmät. Testausmenetelmiä pitäisi kehittää ja muuttaa paremmin kotitalouksien todellista käyttöä vastaa- 
vaksi. Energiamerkittyjen kotitalouskoneiden tulisi toimia arjessa ja olla suunniteltuja kaikille.

- Energiamerkissä annetut tiedot. Energiamerkkiin tarvitaan enemmän tietoa helpottamaan kotitalouksien energian säästöä. Energiamerkintää voisi kehittää siten, että se ohjaa kotitalouksia energiansäästöön.

- Kaupoissa saatava tieto. Myyntihenkilökuntaa pitäisi kouluttaa niin, että he osaavat antaa energiansäästöneuvontaa ostotilanteessa.

- Pienten kotitalouskoneiden kehittäminen. Kotitalouksien pitäisi voida valita kotitalouskoneensa omien tarpeidensa ja käyttötapojensa mukaan. Se edellyttää pienten kotitalouskoneiden saatavuutta. 



\section{Sammanfattning}

Energimärkningen av hushållsmaskiner är obligatorisk och gemensam för EU-länderna. Syftet med energimärkningen är att informera konsumenterna om energiförbrukningen och andra viktiga egenskaper, så konsumenterna ska kunna välja så energisnåla hushållsmaskiner som möjligt. För närvarande omfattas följande hushållsmaskiner av energimärkningen; kyl och frysförvaring, tvättmaskiner, torktumlare samt kombinerade tvättmaskiner och torktumlare, diskmaskiner, och ugnar

De testmetoder som används vid mätning av energieffektiviteten ska avspegla konsumenternas normala användning av hushållsmaskinerna. Vid provning av hushållsmaskiner har bland annat framkommit att hushållsmaskinerna genom energimärkningen förändrats på ett sätt som kan vara till nackdel för konsumenterna. Programmen i tvätt- och diskmaskinerna har förlängts och fyllnadsgraden har höjts i tvättmaskinerna. Det har också visat sig att infrysningskapaciteten har försämrats hos frysarna.

Syftet med projektet var att få svar på hur hushållsmaskinerna på den nordiska marknaden förändrats sedan införandet av energimärkningen samt hur det påverkat hushållens användning av hushållsmaskinerna. I projektet ställdes också frågan om hushållen kan göra ett energiriktigt val med hjälp av den information som ges på energimärkningsetiketten samt om energimärkningen motsvarar normal användning.

I projektet har samlats testresultat från nordiska tester av energimärkta hushållsmaskiner. Personer som testar hushållsmaskiner och generalagenter för försäljning av hushållsmaskiner har intervjuats om hur de ser på energimärkningens inverkan på hushållsmaskinerna. En Internetenkät har utförts av Taloustutkimus Oy i Finland, Norge och Sverige. Målgruppen var 20 till 65-åriga konsumenter som köpt minst en av de energimärkta hushållsmaskinerna; kyl och frysförvaring, diskmaskin, ugn, tvättmaskin och torktumlare. Hushållen svarade på frågor om hur de använder hushållsmaskinerna och vad de anser om den. Hushållen svarade också på frågor om energimärknigen.

Resultaten från projektet visade att energimärkningen fört med sig energieffektivare hushållsmaskiner under den 10-årsperiod den funnits. Främst gäller detta kyl/frysförvaring men även tvättmaskiners och diskmaskiners energiförbrukning har sjunkit. Tvättmaskinerna och diskmaskinerna är energieffektiva delvis på bekostnad av längre programtider. Kylar och frysar har fått ökad isolering vilket lett till mindre volym hos kylar och frysar och frysarnas infrysningskapacitet har försämrats. En förbättring av torktumlarnas energiförbrukning har varit svårare att uppnå, men med hjälp av ny teknik kan den troligen sänkas. Ugnarna har varit energimärkta en kort tid så några slutsatser om hur energimärkning- 
en påverkat ugnarnas energiförbrukning är för tidigt att dra. Det kan dock konstateras att kraven på ugnar är lågt satta, eftersom de flesta ugnar redan från början hamnat i klass A eller B.

Testpersonal av hushållsmaskiner och generalagenter i de nordiska länderna har en likartad uppfattning om att energimärkningen påverkat och styrt produktutvecklingen av hushållsmaskiner.

Energimärkningen har påverkat utvecklingen mot större hushållsmaskiner och urvalet av små hushållsmaskiner är begränsat samtidigt som antalet småhushåll ökar i alla nordiska länder. Stora hushållsmaskiner har lättare att uppfylla kraven i energimärkningen. Både från testpersonal och generalagenter framkom misstankar om att energimärkningen har lett till sämre sköljresultat i tvättmaskinerna. En orsak tros vara den låga vattenförbrukningen i maskinen. Sköljresultatet hos tvättmaskinerna kan inte anges i energimärkningen, eftersom det idag inte finns någon standardiserad metod att mäta sköljeffekten. Av samma skäl kan inte heller stek/gräddningsjämnheten, det vill säga, ugnens funktion, anges i energimärkningen.

Enkäten till de nordiska hushållen visade att över $90 \%$ av de tillfrågade hushållen är nöjda med sina hushållsmaskiner. Ugnarna var man mest nöjd med och torktumlarna var den produktgrupp som det fanns mest missnöje med. I enkäten framkom också att de flesta hushåll inte märkt att volymen hos kylförvaringen minskat eller att infrysningen tar längre tid än tidigare. Hushållens uppfattning är att kyl och frys är fyllda. Hushållen kör fyllda diskmaskiner och sköljer disken före disk i diskmaskinen. Diskmaskinen är ansluten till kallvatten och hushållen använder höga temperaturer vid disk i diskmaskin. Hushållen är också nöjda med disk- och sköljresultatet. Närmare hälften av hushållen tycker att diskmaskinen diskar för länge. Hushållen tvättar vid låga temperaturer och är mycket nöjda med tvättresultatet. Många hushåll tycker att tvättprogrammet tar för lång tid. Majoriteten av hushållen anser inte att tvättmaskinerna sköljer dåligt och funktionen extra skölj hos tvättmaskinerna användes inte så ofta.

Energimärkningen har påverkat produktutvecklingen av hushållsmaskiner. Maskinerna är energisnåla och hushållen är nöjda med sina hushållsmaskiner, men provningsmetoderna som används vid energimärkningsprovningarna motsvarar inte alltid normal användning. Den nuvarande energimärkningen fokuserar starkt på energibesparing, men det är också viktigt att hushållsmaskinerna fungerar. Tack vare energimärkningen får hushåll energieffektiva hushållsmaskiner, men i samband med användningen av hushållsmaskinerna finns det fortfarande energibesparingar att göra.

Ett fortsatt arbeta med att förbättra energimärkningen och öka energibesparingen hos hushållen bör fokuseras på: 
- Studier av hushållens sätt att använda hushållsmaskinerna och hur användningen inverkar på energiförbrukningen. Intervjuer och uppföljningar av hushållens beteende i hemmet, där hushållsmaskinerna finns och används bör göras.

- Provningsmetoderna för energimärkningen. Metoderna bör utvecklas och omarbetas, så de motsvarar normal användning. Ett krav bör vara att energimärkta hushållsmaskiner fungerar bra i vardagslivet och är designade för alla.

- Informationen som ges på energimärkningsetiketten. För att hushållen ska kunna reducera sin energiförbrukning behövs mer information och kunskap än den som ges på energimärkningsetiketten. Initiativ bör tas till att utveckla ett märkningssystem som vägleder hushållen att spara energi.

- Informationen som ges i butiken. Försäljningspersonalen bör utbildas så de kan lämna information om energibesparing vid köptillfället.

- Utveckling av små attraktiva hushållsmaskiner. Hushållen bör kunna välja hushållsmaskiner utifrån sina behov och sätt att använda maskinen. Det förutsätter att det finns ett urval av små hushållsmaskiner på marknaden. 



\section{Appendix 1}

\section{Refrigerators}

Table 4 Average usable volume of the refrigerators.

\begin{tabular}{llllll}
\hline $2000(n=17)$ & $2001(n=10)$ & $2002(n=15)$ & $2003(n=6)$ & $2004(n=13)$ & $2005(n=7)$ \\
\hline 231 & 348 & 175 & 340 & 340 & 223
\end{tabular}

Table 5 Average total energy consumption of the refrigerators, kWh/day.

\begin{tabular}{llllll}
\hline $2000(n=17)$ & $2001(n=10)$ & $2002(n=15)$ & $2003(n=6)$ & $2004(n=13)$ & $2005(n=7)$ \\
\hline 0.51 & 0.56 & 0.64 & 0.50 & 0.44 & 0.47 \\
\hline
\end{tabular}

Table 6 Average specific energy consumption of the refrigerators, kWh/100 I / day.

\begin{tabular}{llllll}
\hline $2000(n=17)$ & $2001(n=10)$ & $2002(n=15)$ & $2003(n=6)$ & $2004(n=13)$ & $2005(n=7)$ \\
\hline 0.22 & 0.16 & 0.38 & 0.38 & 0.13 & 0.22 \\
\hline
\end{tabular}

\section{Fridge-freezers}

Table 7 Average usable volume of the fridge-freezers, I.

\begin{tabular}{lllll}
\hline $1995(n=14)$ & $2000(n=9)$ & $2002(n=32)$ & $2004(n=27)$ & $2005(n=25)$ \\
\hline 307 & 309 & 301 & 318 & 318 \\
\hline
\end{tabular}

Table 8 verage total energy consumption of the fridge-freezers, $k W h / d a y$.

\begin{tabular}{lllll}
\hline $\mathbf{1 9 9 5}(\mathbf{n}=\mathbf{1 4})$ & $\mathbf{2 0 0 0 ( n = 9 )}$ & $\mathbf{2 0 0 2 ( n = 3 2 )}$ & $\mathbf{2 0 0 4 ( n = 2 7 )}$ & $\mathbf{2 0 0 5 ( n = 2 5 )}$ \\
\hline 1.50 & 1.16 & 1.07 & 0.91 & 0.96 \\
\hline
\end{tabular}

Table 9 Average specific energy consumption of the fridge-freezers, $k W h / 100$ I / day.

\begin{tabular}{lllll}
\hline $\mathbf{1 9 9 5}(\mathrm{n}=\mathbf{1 4})$ & $\mathbf{2 0 0 0 ( n = 9 )}$ & $\mathbf{2 0 0 2}(\mathrm{n}=\mathbf{3 2})$ & $\mathbf{2 0 0 4}(\mathrm{n}=\mathbf{2 7})$ & $\mathbf{2 0 0 5}(\mathrm{n}=\mathbf{2 5})$ \\
\hline 0.49 & 0.38 & 0.36 & 0.29 & 0.32 \\
\hline
\end{tabular}

\section{Freezers}

Table 10 verage usable volume of the freezers, I.

\begin{tabular}{llll}
\hline $1996(n=15)$ & $2003(n=13)$ & $2004(n=10)$ & $2005(n=7)$ \\
\hline 245 & 227 & 236 & 178 \\
\hline
\end{tabular}


Table 11 verage total energy consumption of the freezers, kWh/day

\begin{tabular}{llll}
\hline $1996(n=15)$ & $2003(n=13)$ & $2004(n=10)$ & $2005(n=7)$ \\
\hline 1.27 & 1.04 & 0.61 & 0.74 \\
\hline
\end{tabular}

Table 12 Average energy consumption of the freezers kWh/100 I / day.

\begin{tabular}{llll}
\hline $1996(n=15)$ & $2003(n=13)$ & $2004(n=10)$ & $2005(n=7)$ \\
\hline 0.51 & 0.47 & 0.26 & 0.49 \\
\hline
\end{tabular}

\section{Dishwashers}

Table 13 Load of the dishwashers, settings.

\begin{tabular}{llllllll}
\hline $1998(n=5)$ & $1999(n=10)$ & $2000(n=9)$ & $2001(n=9)$ & $2002(n=11)$ & $\mathbf{2 0 0 3 ( n = 8 )}$ & $\mathbf{2 0 0 4}(n=19)$ & $2005(n=17)$ \\
\hline 12 & $8-12$ & 12 & $3-12$ & 12 & $6-12$ & $5-12$ & 12 \\
\hline
\end{tabular}

Table 14 ashing temperature of the dishwashers, set.

\begin{tabular}{llllllll}
\hline $1998(n=5)$ & $1999(n=10)$ & $2000(n=9)$ & $2001(n=9)$ & $2002(n=11)$ & $2003(n=8)$ & $2004(n=19)$ & $2005(n=17)$ \\
\hline- & $50-65$ & $45-50$ & 65 & $50-55$ & - & $50-55$ & $45-55$ \\
\hline
\end{tabular}

Table 15 verage total water consumption of the dishwashers, I.

\begin{tabular}{lllllllll}
\hline $\begin{array}{l}1994 \\
(n=15)\end{array}$ & $1998(n=5)$ & $\begin{array}{l}1999 \\
(n=10)\end{array}$ & $2000(n=9)$ & $2001(n=9)$ & $\begin{array}{l}2002 \\
(n=11)\end{array}$ & $2003(n=8)$ & $\begin{array}{l}2004 \\
(n=19)\end{array}$ & $\begin{array}{l}2005 \\
(n=17)\end{array}$ \\
\hline 24 & 16 & 19 & 18 & 15 & 17 & 12 & 13 & 14 \\
\hline
\end{tabular}

Table 16 Average specific water consumption of the dishwashers, l/setting

\begin{tabular}{lllllllll}
\hline $\begin{array}{l}1994 \\
(n=15)\end{array}$ & $1998(n=5)$ & $\begin{array}{l}1999 \\
(n=10)\end{array}$ & $2000(n=9)$ & $2001(n=9)$ & $\begin{array}{l}2002 \\
(n=11)\end{array}$ & $2003(n=8)$ & $\begin{array}{l}2004 \\
(n=19)\end{array}$ & $\begin{array}{l}2005 \\
(n=17)\end{array}$ \\
\hline 2.1 & 1.3 & 1.7 & 1.5 & 2.1 & 1.4 & 1.2 & 1.3 & 1.2 \\
\hline
\end{tabular}

Table 17 verage total energy consumption of the dishwashers, $\mathrm{kWh}$.

\begin{tabular}{lllllllll}
\hline $\begin{array}{l}1994^{1} \\
(n=15)\end{array}$ & $1998(n=5)$ & $\begin{array}{l}1999 \\
(n=10)\end{array}$ & $2000(n=9)$ & $2001(n=9)$ & $\begin{array}{l}2002 \\
(n=11)\end{array}$ & $2003(n=8)$ & $\begin{array}{l}2004 \\
(n=19)\end{array}$ & $\begin{array}{l}2005 \\
(n=17)\end{array}$ \\
\hline 0,83 & 1,23 & 1,42 & 1,23 & 1,09 & 1,21 & 1,03 & 1,11 & 1,13 \\
\hline
\end{tabular}

Table 18 verage specific energy consumption of the dishwashers, kWh/setting

\begin{tabular}{lllllllll}
\hline $\begin{array}{l}1994 \\
(n=15)\end{array}$ & $1998(n=5)$ & $\begin{array}{l}1999 \\
(n=10)\end{array}$ & $2000(n=9)$ & $2001(n=9)$ & $\begin{array}{l}2002 \\
(n=11)\end{array}$ & $2003(n=8)$ & $\begin{array}{l}2004 \\
(n=19)\end{array}$ & $\begin{array}{l}2005 \\
(n=17)\end{array}$ \\
\hline 0.07 & 0.10 & 0.13 & 0.10 & 0.14 & 0.10 & 0.1 & 0.10 & 0.09 \\
\hline
\end{tabular}

Table 19. Average programme time of the dishwashers, $\min$.

\begin{tabular}{|c|c|c|c|c|c|c|c|c|}
\hline $\begin{array}{l}1994 \\
(n=15)\end{array}$ & $1998(n=5)$ & $\begin{array}{l}1999 \\
(n=10)\end{array}$ & $2000(n=9)$ & $2001(n=9)$ & $\begin{array}{l}2002 \\
(n=11)\end{array}$ & $2003(n=8)$ & $\begin{array}{l}2004 \\
(n=19)\end{array}$ & $\begin{array}{l}2005 \\
(n=17)\end{array}$ \\
\hline 60 & 144 & 88 & 131 & 95 & 132 & 156 & 157 & 152 \\
\hline
\end{tabular}

\footnotetext{
${ }^{1}$ With warm water supply
} 


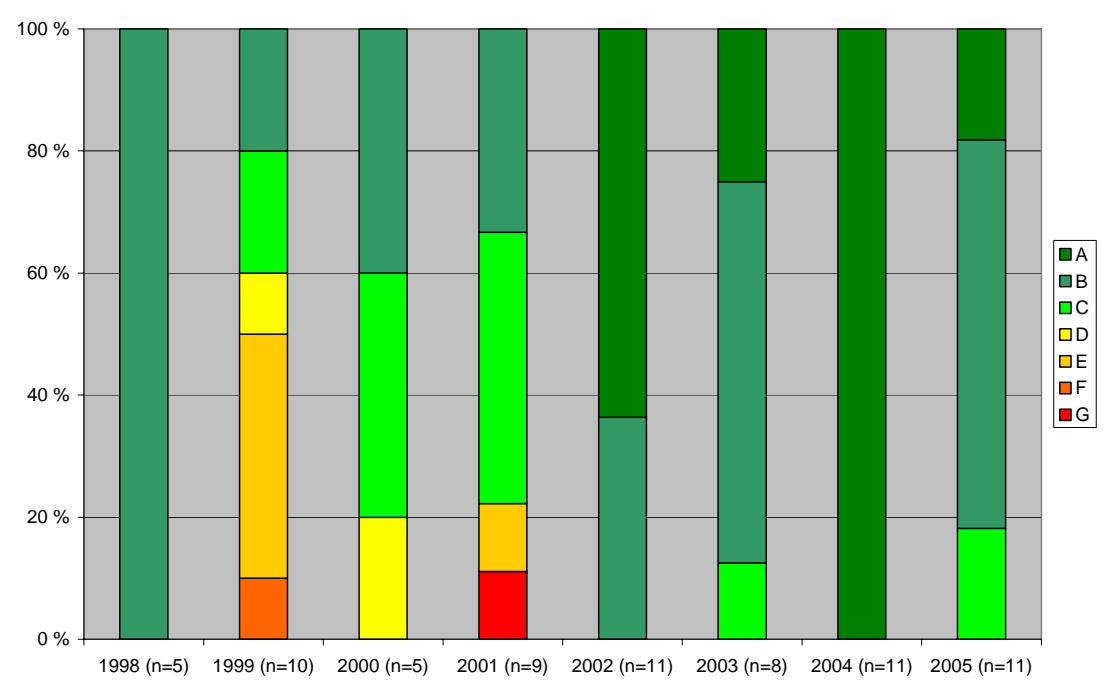

Figure 24 Distribution of dishwashers tested in the Nordic countries in 1998-2005 into classes of cleaning efficiency.

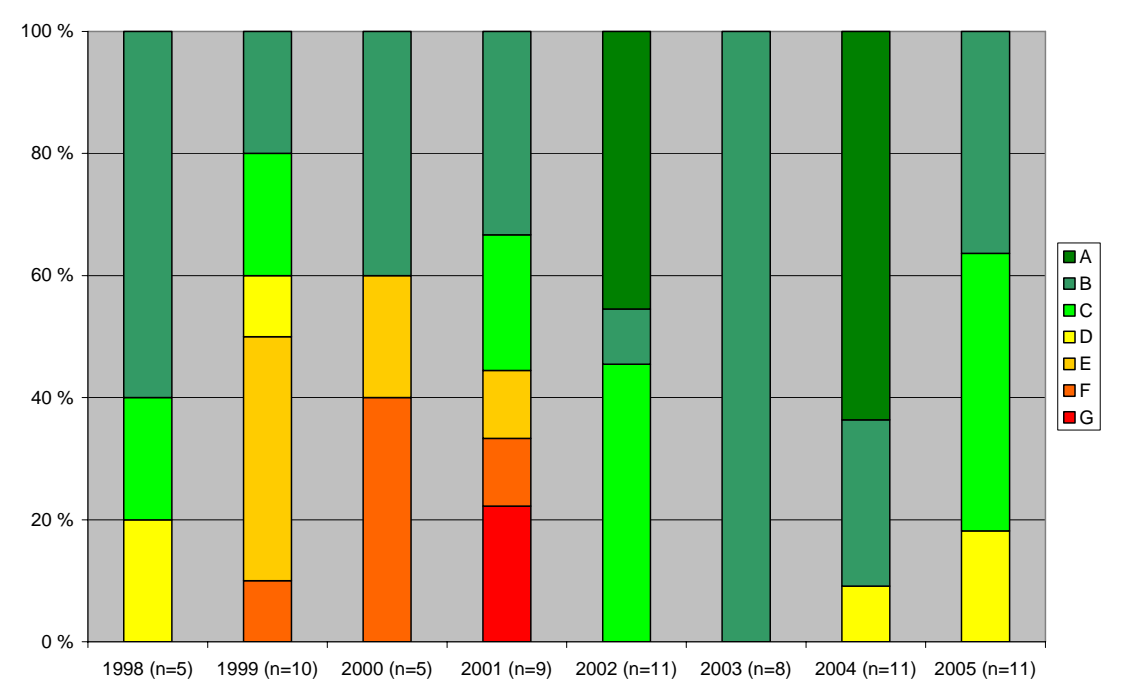

Figure 25 Distribution of dishwashers tested in the Nordic countries in 1998-2005 into classes of drying efficiency.

\section{Washing machines}

Table 20 Average load weight of the washing machines, $\mathrm{kg}$.

\begin{tabular}{|c|c|c|c|c|c|c|}
\hline $1996(n=15)$ & $2000(n=29)$ & $2001(n=28)$ & $2002(n=26)$ & $2003(n=12)$ & 2004 & $2005(n=19)$ \\
\hline 4.3 & 4.7 & 5.1 & 4.5 & 4.9 & 5.5 & 5.2 \\
\hline & $2000(n=20)$ & 2001 & 2002 & $2003(n=12)$ & 2004 & $2005(n=19 / 10$ \\
\hline set & 1263 & 1197 & 1100 & 1233 & 1369 & 1284 \\
\hline $\max$ & & 1343 & 1245 & & 1316 & 1249 \\
\hline
\end{tabular}


Table 22 Average maximum washing temperature of the washing machines, ${ }^{\circ} \mathrm{C}$.

\begin{tabular}{|c|c|c|c|c|c|}
\hline $1996(n=15)$ & $2000(n=2)$ & $2001(n=19)$ & $2002(n=16)$ & $2003(n=4)$ & $2004(n=12)$ \\
\hline 57 & 59 & 54 & 53 & 55 & 53 \\
\hline
\end{tabular}

Table 23 verage total water consumption of the washing machines, I.

\begin{tabular}{|c|c|c|c|c|c|c|}
\hline $1996(n=15)$ & $2000(n=29)$ & $2001(n=28)$ & $2002(n=26)$ & $2003(n=12)$ & $2004(n=30)$ & $2005(n=19)$ \\
\hline 67 & 55 & 56 & 50 & 58 & 53 & 53 \\
\hline
\end{tabular}

Table 24 verage specific water consumption of the washing machines, I / kg

\begin{tabular}{lllllll}
\hline $\mathbf{1 9 9 6}(n=15)$ & $\mathbf{2 0 0 0}(\mathrm{n}=\mathbf{2 9})$ & $\mathbf{2 0 0 1}(\mathrm{n}=\mathbf{2 8})$ & $\mathbf{2 0 0 2}(\mathrm{n}=\mathbf{2 6})$ & $\mathbf{2 0 0 3}(\mathrm{n}=12)$ & $\mathbf{2 0 0 4}(\mathrm{n}=20)$ & $\mathbf{2 0 0 5}(\mathrm{n}=19)$ \\
\hline 16 & 12 & 11 & 12 & 13 & 10 & 10 \\
\hline
\end{tabular}

Table 25 Average total energy consumption of the washing machines, kWh.

\begin{tabular}{|c|c|c|c|c|c|c|}
\hline $1996(n=15)$ & $2000(n=23)$ & $2001(n=28)$ & $2002(n=26)$ & $2003(n=12)$ & $2004(n=30)$ & $2005(n=19)$ \\
\hline 1,03 & 1,05 & 1,10 & 0,99 & 1,07 & 1,09 & 1,05 \\
\hline
\end{tabular}

Table 26 Average specific energy consumption of washing machines, $\mathrm{kWh} / \mathrm{kg}$

\begin{tabular}{lllllll}
\hline $1996(n=15)$ & $2000(n=23)$ & $\mathbf{2 0 0 1}(n=28)$ & $\mathbf{2 0 0 2}(n=26)$ & $\mathbf{2 0 0 3 ( n = 1 2 )}$ & $\mathbf{2 0 0 4}(n=20)$ & $\mathbf{2 0 0 5}(n=19)$ \\
\hline 0.25 & 0.23 & 0.22 & 0.22 & 0.23 & 0.21 & 0.20 \\
\hline
\end{tabular}

Table 27 Average programme time of washing machines, min.

\begin{tabular}{lllllll}
\hline $1996(n=15)$ & $2000(n=23)$ & $2001(n=28)$ & $2002(n=16)$ & $2003(n=12)$ & $2004(n=28)$ & $2005(n=19)$ \\
\hline 110 & 125 & 130 & 129 & 131 & 134 & 135 \\
\hline
\end{tabular}

Table 28 Average moisture content of the washing machines after spinning, \%.

\begin{tabular}{|c|c|c|c|c|c|c|}
\hline $1996(n=15)$ & $2000(n=29)$ & $2001(n=28)$ & $2002(n=26)$ & $2003(n=12)$ & $2004(n=26)$ & $2005(n=19)$ \\
\hline 72 & 54 & 57 & 57 & 54 & 51 & 55 \\
\hline
\end{tabular}




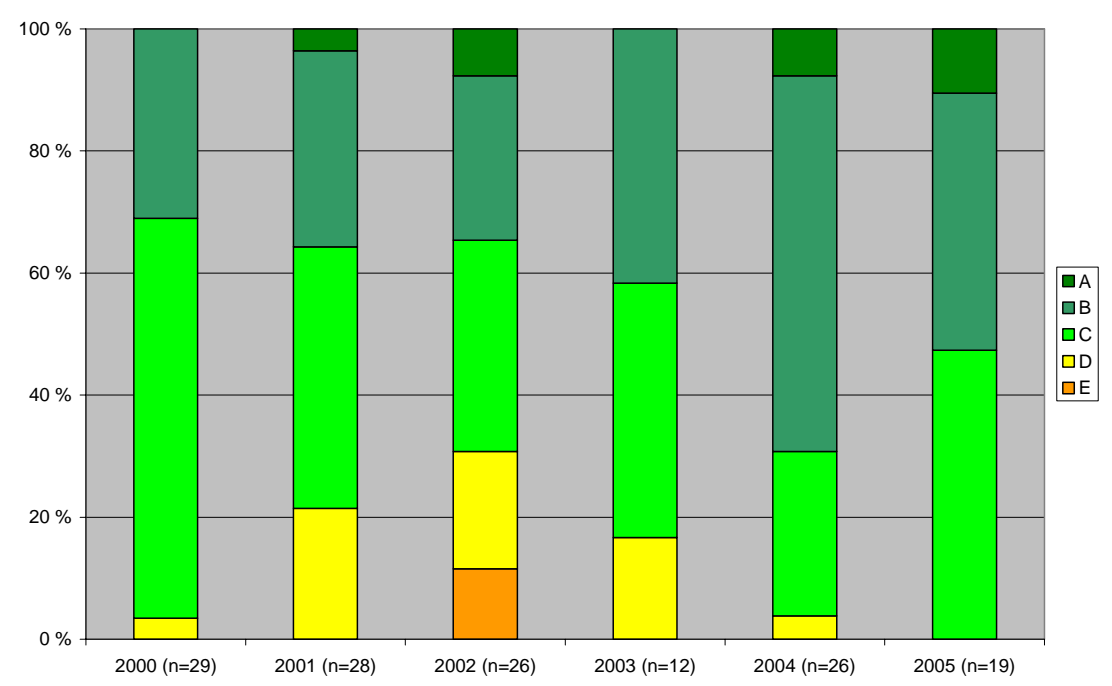

Figure 26 Distribution of washing machines tested in the Nordic countries in 2000-2005 into classes of washing efficiency.

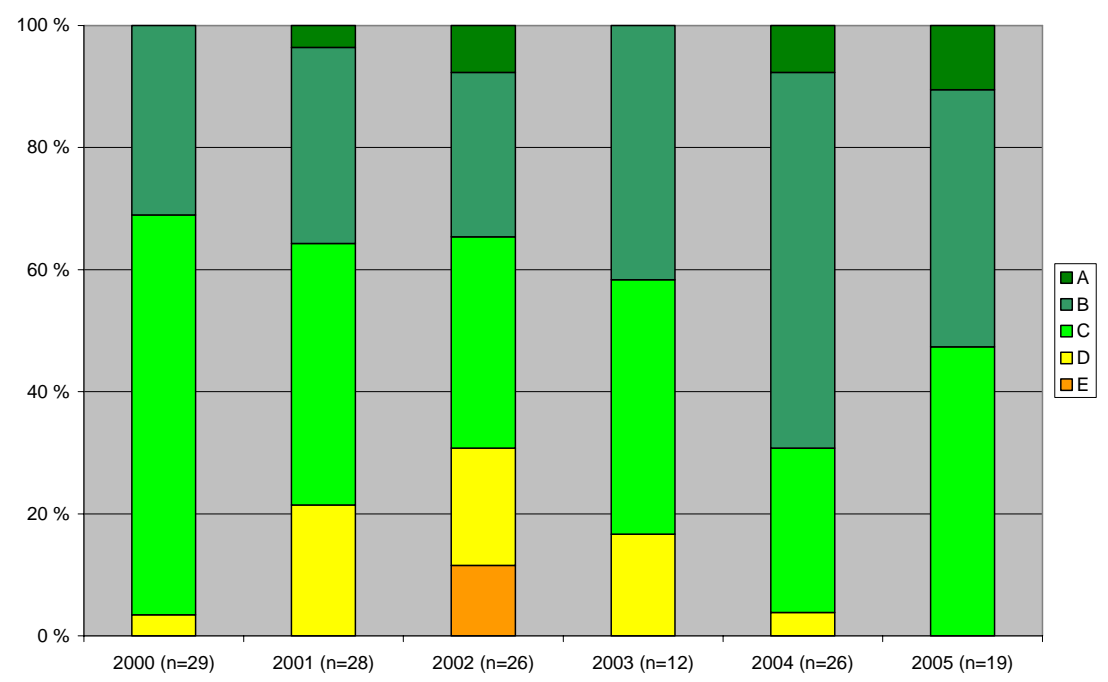

Figure 27 Distribution of washing machines tested in the Nordic countries in 2000-2005 into classes of spin-drying efficiency

\section{Tumble driers}

Table 31. Average load weight of the tumble driers, $\mathrm{kg}$.

\begin{tabular}{llllllll}
\hline $1997(n=7)$ & $1999(n=10)$ & $2000(n=7)$ & $2001(n=9)$ & $2002(n=10)$ & $2003(n=10)$ & $2004(n=2)$ & $2005(n=7)$ \\
\hline 5.1 & 4.8 & 4.7 & 5 & 5.1 & 5.4 & 5.5 & 5.4 \\
\hline
\end{tabular}

Table 32. Average total energy consumption of the tumble driers, kWh.

\begin{tabular}{llllllll}
\hline $1997(n=7)$ & $1999(n=10)$ & $2000(n=7)$ & $2001(n=9)$ & $2002(n=10)$ & $2003(n=10)$ & $2004(n=2)$ & $2005(n=7)$ \\
\hline 4.06 & 3.45 & 3.57 & 3.96 & 3.62 & 4.23 & 4.15 & 4.15 \\
\hline
\end{tabular}


Table 33 verage energy consumption of the tumble driers, $\mathrm{kWh} / \mathrm{kg}$.

\begin{tabular}{llllllll}
$1997(n=7)$ & $1999(n=10)$ & $2000(n=7)$ & $2001(n=9)$ & $2002(n=10)$ & $2003(n=10)$ & $2004(n=2)$ & $2005(n=7)$ \\
\hline 0.79 & 0.72 & 0.77 & 0.81 & 0.71 & 0.78 & 0.76 & 0.77
\end{tabular}

Table 34 Average programme time of the tumble driers, min.

\begin{tabular}{llllllll}
\hline $1997(n=7)$ & $1999(n=10)$ & $2000(n=7)$ & $2001(n=9)$ & $2002(n=10)$ & $2003(n=10)$ & $2004(n=2)$ & $2005(n=7)$ \\
\hline 116 & 112 & 120 & 119 & 121 & 129 & 129 & 135 \\
\hline
\end{tabular}

\section{Ovens}

Table 35 verage usable volume of the ovens, I

\begin{tabular}{|c|c|c|}
\hline $2003(n=12)$ & $2004(n=22)$ & $2005(n=11)$ \\
\hline 48 & 52 & 53 \\
\hline
\end{tabular}

Table 33 Average usable surface area, $\mathrm{cm}^{2}$.

\begin{tabular}{lll}
\hline $2003(n=12)$ & $2004(n=22)$ & $2005(n=11)$ \\
\hline 1290 & 1243 & 1178 \\
\hline
\end{tabular}

Table 34 Average total energy consumption of the ovens, kWh.

\begin{tabular}{lll}
\hline $2003(n=12)$ & $2004(n=22)$ & $2005(n=11)$ \\
\hline 0.90 & 0.95 & 0.89 \\
\hline
\end{tabular}

